\title{
Adenosine and the Cardiovascular System: The Good and the Bad
}

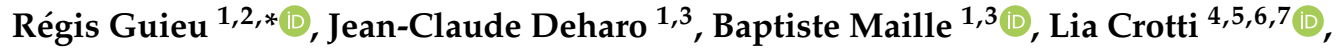 \\ Ermino Torresani ${ }^{8}$, Michele Brignole ${ }^{8,9}$ (D) and Gianfranco Parati ${ }^{4,8}$ (D) \\ 1 C2VN INSERM, INRAE, Aix Marseille University, 13005 Marseille, France; \\ jean-claude.deharo@ap-hm.fr (J.-C.D.); baptiste.maille@ap-hm.fr (B.M.) \\ 2 Laboratory of Biochemistry, Timone Hospital, 13005 Marseille, France \\ 3 Department of Cardiology, Hôpital La Timone Adultes, 13005 Marseille, France \\ 4 Department of Medicine and Surgery, University of Milano Bicocca, 20122 Milan, Italy; \\ 1.crotti@auxologico.it (L.C.); gianfranco.parati@unimib.it (G.P.) \\ 5 IRCCS, Department of Cardiovascular, Istituto Auxologico Italiano, Neural and Metabolic Sciences, \\ San Luca Hospital, 20122 Milan, Italy \\ 6 IRCCS, Istituto Auxologico Italiano, Cardiomyopathy Center and Center for Cardiac Arrhythmias of Genetic \\ Origin, 20122 Milan, Italy \\ 7 IRCCS, Laboratory of Cardiovascular Genetics, Istituto Auxologico Italiano, 20122 Milan, Italy \\ 8 IRCCS Istituto Auxologico Italiano, Faint \& Fall Programme, Ospedale San Luca, 20122 Milano, Italy; \\ e.torresani@auxologico.it (E.T.); mbrignole@outlook.it (M.B.) \\ 9 Department of Cardiology, Arrhythmology Centre and Syncope Unit, Ospedali del Tigullio, \\ 16033 Lavagna, Italy \\ * Correspondence: guieu.regis@orange.fr
}

Received: 5 April 2020; Accepted: 29 April 2020; Published: 6 May 2020

\begin{abstract}
Adenosine is a nucleoside that impacts the cardiovascular system via the activation of its membrane receptors, named $A_{1} R, A_{2 A} R, A_{2 B} R$ and $A_{3} R$. Adenosine is released during hypoxia, ischemia, beta-adrenergic stimulation or inflammation and impacts heart rhythm and produces strong vasodilation in the systemic, coronary or pulmonary vascular system. This review summarizes the main role of adenosine on the cardiovascular system in several diseases and conditions. Adenosine release participates directly in the pathophysiology of atrial fibrillation and neurohumoral syncope. Adenosine has a key role in the adaptive response in pulmonary hypertension and heart failure, with the most relevant effects being slowing of heart rhythm, coronary vasodilation and decreasing blood pressure. In other conditions, such as altitude or apnea-induced hypoxia, obstructive sleep apnea, or systemic hypertension, the adenosinergic system activation appears in a context of an adaptive response. Due to its short half-life, adenosine allows very rapid adaptation of the cardiovascular system. Finally, the effects of adenosine on the cardiovascular system are sometimes beneficial and other times harmful. Future research should aim to develop modulating agents of adenosine receptors to slow down or conversely amplify the adenosinergic response according to the occurrence of different pathologic conditions.
\end{abstract}

Keywords: adenosine receptors; cardiovascular diseases

\section{Introduction}

Adenosine is a ubiquitous nucleoside that comes from the dephosphorylation of ATP and AMP. It is released specifically during hypoxia, ischemia, inflammation and beta-adrenergic stimulation [1-5]. Adenosine acts on a number of tissues (including the immune and nervous systems) through the activation of four G-coupled membrane receptors, named A1R, A2AR, A2BR and A3R, as a function of 
their pharmacological properties and primary sequence [6-8]. Adenosine also strongly impacts the cardiovascular system mainly through the activation of its receptors. The main effects of adenosine on the cardiovascular system involve heart rate, vasomodulation and blood pressure regulation. The goal of this review is to summarize the impact of adenosine and its receptor activation during several cardiovascular diseases and conditions.

\section{Source and Mechanism of Action of Adenosine}

Adenosine is synthetized in most cells, but the main sources of adenosine in blood are endothelial and muscle cells, through the dephosphorylation of AMP via specific nucleotidases. Adenosine release also occurs after adrenergic stimulation. Part of adenosine production comes from the methionine cycle (see Figure 1). At the extracellular level, adenosine comes from the dephosphorylation of ATP and AMP via the membrane clusters CD39 and CD73, respectively.



Figure 1. Representation of adenosine metabolism.

Aside of CD39, pyrophosphatases (ENPP1/3) is expressed in many tissues including macrophages and can degrade ATP to AMP leading to enhance adenosine production [9].

Intracellular adenosine leaves the cells via an equilibrative facilitated diffusion system (ENT for equilibrative nucleoside transporter) [10,11]. In the extracellular spaces, the half-life of adenosine is short due to its uptake by red blood cells (see Figure 1). During hypoxia, ischemia, or inflammation, the release of adenylyl nucleotides increases, and adenosine concentration increases at both intra- and extracellular levels $[2,4,12]$.

Schematic representation of adenosine metabolism.

Adenosine is synthesized in most mammalian cells via the dephosphorylation of AMP through nucleotidases. Part of the adenosine comes from the metabolism of methionine. Adenosine is released in the extracellular spaces via an equilibrative nucleoside transporter (ENT). The trigger of adenosine release is mainly hypoxia and inflammation. Adenosine is also converted into inosine and then to xanthine and finally to uric acid, the final product, via adenosine deaminase (ADA) and xanthine oxidase $(\mathrm{XO})$, respectively. In the extracellular spaces, adenosine is formed by the dephosphorylation of ATP and 5'AMP via CD39 and CD73, respectively. Adenosine activates four G-coupled membrane receptors, named $A_{1} R, A_{2 A} R, A_{2 B} R$, and $A_{3} R$. Schematically, activation of $A_{1} R$ leads to slowing of the 
heart rate, while activation of $A_{2} R$ leads to vasodilation. Finally, $A_{3} R$ is implicated in the protection against the ischemia/reperfusion process.

\section{Adenosine Receptors}

Adenosine impacts the cardiovascular system via $\mathrm{A}_{1}, \mathrm{~A}_{2 \mathrm{~A}}, \mathrm{~A}_{2 \mathrm{~B}}$, and $\mathrm{A}_{3}$ receptor subtypes. All four receptor subtypes have been detected in the heart, with subtype distributions varying from one tissue to another [13]. $A_{1} R$ possesses high affinity for adenosine and is expressed throughout the cardiovascular system at high levels in the atria [14]. $\mathrm{A}_{1} \mathrm{R}$ expression varies in cardiac tissues with higher levels in the right atrium than in the left atrium and lower expression in ventricular myocytes than in the atrium [15]. $A_{1} R$ is also expressed in smooth muscles and endothelial coronary tissues [16]. $A_{2 A} R$ is widely expressed in the cardiovascular system but particularly in vessels [17], atria, and ventricular tissues $[14,18]$. In ventricular myocytes, activation of $A_{2 A} R$ leads to inotropic properties $[19,20]$. $A_{2 B} R$ possesses the lowest affinity for adenosine. $A_{2 B} R$ is expressed on myocytes and fibroblasts and is reported to modulate ventricular function in animals [20]. $A_{2 B} R$ is also expressed in smooth muscles of coronary arteries mediating vasodilation [21]. $\mathrm{A}_{3} \mathrm{R}$ myocardial expression is very low. Its expression, however, can be observed within the heart and appears to play a role in coronary artery muscle cells but also in other smooth muscle cells [22-24].

$\mathrm{A}_{1} \mathrm{R}$ stimulation leads to a decrease in cAMP production in target cells, which results in the inhibition of protein kinase A (PKA) and voltage-gated calcium channels and activation of phospholipase $C$ [6-8]. Activation of $A_{1} R$ also leads to direct activation (cAMP-independent) of the inwardly rectifying $\mathrm{K}+$ current $\left(\mathrm{IK}_{\mathrm{Ado}}\right)$. Activation of $\mathrm{A}_{2 \mathrm{~A}} \mathrm{R}$ also inhibits voltage-gated $\mathrm{Ca}++$ channels [25]. Schematically, activation of $A_{1} R$ leads to bradycardia or atrioventricular block (AVB), while activation of $A_{2 A} R$ and, to a less extent, of $A_{2 B} R$ leads to vasodilation via $N O$ and $K_{A T P}$ channels [26]. $A_{2 A} R$ also inhibits L Type calcium currents [25]. Despite opposite effects on cAMP production in target cells, there is some overlap between the cardiovascular effects following $A_{1} R$ or $A_{2 A} R$ activation. As an example, activation of $A_{1} R$ leads mainly to a decrease in heart rate, but $K O$ mice for $A_{2 A} R$ exhibit tachycardia, suggesting that $A_{2 A} R$ activation leads to a reduction in heart rate [27]. $A_{3}$ Rs are implicated more specifically in ischemia/reperfusion protection, but all receptor subtypes seem to be implicated in ischemia myocardium protection [7]. Finally, $A_{2 A}$ and $A_{2 B}$ receptors are expressed on platelets, where their activation leads to antiplatelet properties via calcium flux inhibition [28].

Finally, a specific pharmacological profile, called the receptor of reserve, was described in some diseases, such as coronary artery disease or syncope [29]. It seems that this type of receptor, which is characterized by maximal biological effects (evaluated by cAMP production) while only a weak proportion of receptors are activated by the ligand [30], is an adaptive response to compensate for low adenosine levels, low receptor expression levels or both [29]. The precise role of this kind of receptor needs further investigation.

\section{Effects of Adenosine on Vessels}

Adenosine is known to regulate coronary blood flow (CBF) [31] and exerts potent vasodilatory effects in most vascular beds of mammalian species [32]. These effects are secondary to the activation of $A_{2 A} R[17,30,33]$ and $A_{2 B}$ receptors [34] and occur via the production of cAMP in smooth muscle cells [17] and the activation of $\mathrm{Kv}, \mathrm{K}_{\mathrm{ATP}}$ channels and NO pathways, both in peripheral arterial vessels $[35,36]$ and in coronary arteries [26,37]. Mice with $\mathrm{A}_{2 \mathrm{~A}} \mathrm{R} \mathrm{KO}$ exhibit hypertension, tachycardia, and platelet aggregation abnormalities [27].

\section{Effects of Adenosine on the Sinus Node and Atrio-Ventricular Junction (Figure 2)}

Adenosine suppresses the activity of cardiac pacemakers at the sinus node, atrioventricular node and His bundle [38]. Adenosine has negative dromotropic effects that result in an increase in the PR interval as well as in complete AVB. This effect is secondary to the hyperpolarization of cell 
membranes on the AVN [39]. This action is mediated mainly through the $A_{1} R$ (see Figure 2) via the direct (cAMP independent) activation of the inwardly rectifying $\mathrm{IK}_{\mathrm{Ado}, \mathrm{Ach}}$ currents [40]. Adenosine and acetylcholine, through $A_{1} R$ and $M_{2}$ muscarinic receptor activation, respectively, have very similar effects on cardiomyocytes, both leading to the activation of $\mathrm{IK}_{\mathrm{Ado}, \mathrm{Ach}}$. Adenosine through $\mathrm{A}_{1} \mathrm{R}$ induces the inhibition of hyperpolarization-activated (funny) currents $[25,41]$. Funny channels are activated by cAMP as well as by voltage hyperpolarization and are implicated in the increase in heart rate by catecholamines [42]. Thus, these antiadrenergic effects can also play a role in the negative chronotropic effect of adenosine [39]. The negative chronotropic action of adenosine on the myocardium was also attributed to the inhibition of the inward calcium current (Ica) [40].

Adenosine shortens action potential duration and increases refractoriness $[39,40,43]$. These effects are mainly mediated by the activation of $A_{1} R$. In the atria, adenosine exerts direct and indirect anti-beta-adrenergic effects. The activation of $\mathrm{IK}_{\mathrm{Ado}}$, Ach via $\mathrm{A}_{1} \mathrm{R}$ leads to shortening of action potential duration and refractoriness [43], thus facilitating reentry mechanisms and atrial arrhythmias [39]. Thus, overexpression of $A_{1} R$ is associated with bradycardia, delayed conduction through the sinoatrial and atrioventricular nodes, atrial arrhythmia, and ventricular hypertrophy [44,45].

It was also supposed that the activation of $\mathrm{A}_{2 \mathrm{~A}} \mathrm{R}$ stimulates the ryanodine receptors that control part of the intracellular calcium flux from the sarcoplasmic storage site [46].

On the sinus node, the activation of vagal efferent fibers via the modulation of $\mathrm{M} 2 \mathrm{R}$ and via the activation of $A_{1} R$ have very similar effects, leading to a slower heart rate.

AVN: atrioventricular node

GIRK: G-protein inwardly rectifying potassium channels

$\mathrm{K}: \mathrm{ATP}_{\mathrm{V}}$ : ATP-sensitive and voltage-sensitive potassium channels, respectively.

M2: M2 muscarinic receptors

$\mathrm{SN}$ : sinus node

VDCC: voltage-dependent calcium channels

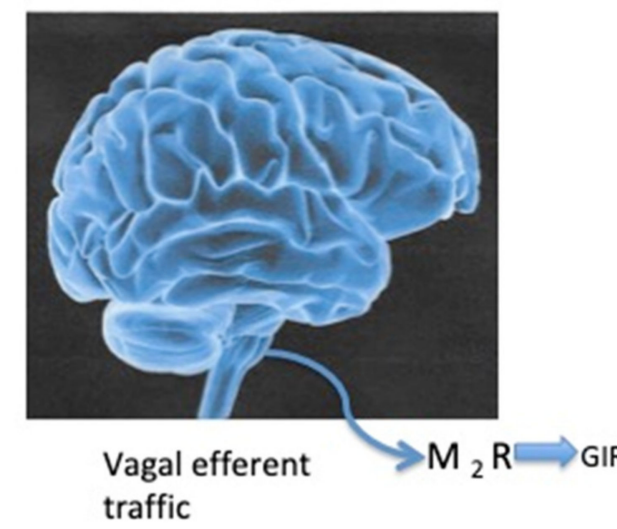

traffic


Figure 2. Schematic representation of the action of adenosine or vagal efferent fibers on the heart and vessels. 


\section{Adenosine and Ventricular Myocytes}

Adenosine exerts anti-beta-adrenergic effects in ventricular myocytes and reduces the cAMP concentration via $A_{1} R$ activation [47]. Adenosine inhibits the adrenergic-dependent increase in inward L-Type Ca++ currents and reduces the amplitude of delayed afterdepolarization [48]. Adenosine terminates episodes of ventricular tachycardia and abolishes the delayed after depolarization associated with digoxin toxicity [49]. These antiarrhythmic effects of adenosine at the ventricular level are mediated mainly by its anti-beta-adrenergic effects [50].

\section{Clinical Aspects}

\subsection{Adenosine and Atrial Fibrillation}

Atrial fibrillation (AF) is the most common arrhythmia that affects $1 \%$ to $4 \%$ of the population [51]. The onset of AF is associated with both vagal and sympathetic activation, with vagal activity being responsible for the decrease in refractory period [52], while sympathetic activation is responsible for atrial activation via calcium release [53]. Both intrinsic and extrinsic autonomic nervous system influences are implicated in the onset of AF [54]. Since the onset of atrial fibrillation is mostly due to ectopic beats originating in the pulmonary veins $[55,56]$, isolation of the pulmonary vein by catheter ablation is effective $[57,58]$. The adenosine test has a high predictive value for AF recurrence after pulmonary vein isolation [59].

Several experimental and observational findings suggest that the adenosinergic system is likely to be implicated in the onset of paroxysmal AF and probably in its maintenance in persistent form. The administration of exogenous adenosine induces AF in susceptible patients $[60,61]$. In patients suffering from supraventricular tachycardia, adenosine administration led to AF or flutter in $12 \%$ of cases, and atrial premature complexes occurred in $58 \%$ of cases [62]. In patients with paroxysmal AF, the infusion of adenosine and isoproterenol in sinus rhythm was able to induce atrial ectopic beats in most patients [63]. High adenosine plasma levels (APL) have been found in the left atria of patients during episodes of paroxysmal and persistent AF, APL normalized during spontaneous resolution of this arrhythmia or after direct cardioversion treatment [64] (see Table 1). Peripheral APL is also high in permanent $\mathrm{AF}$, and this finding has been attributed to peripheral hypoxemia caused by the decrease in left ventricular output [64]. High serum uric acid, the final product of adenosine metabolism, was found to be associated with $\mathrm{AF}$ [65-67]. $\mathrm{A}_{2 \mathrm{~A}}$ receptors are expressed in the right atrium in humans, and their distribution overlaps ryanodine receptors [46]. Abnormal expression levels of $A_{2 A} R$, the activation of which leads to calcium release from the sarcoplasmic reticulum of cardiomyocytes, have been described in patients with AF [68]. Finally, heterogeneous expression of $A_{1} R$ and high expression of G-protein-coupled inwardly rectifying potassium channels have been observed in the right atria of susceptible patients, suggesting that adenosine-induced AF is driven by localized reentry in the right atria [69]. Thus, both $\mathrm{A}_{1} \mathrm{R}$ and $\mathrm{A}_{2 \mathrm{~A}} \mathrm{R}$ are suspected to be implicated in $\mathrm{AF}$ pathophysiology.

Table 1. Main purine abnormalities in human cardiovascular disease.

\begin{tabular}{cc}
\hline Disease & Purinergic Abnormalities \\
\hline Atrial fibrillation & $\begin{array}{c}\text { High APL in the left atria [64]. } \\
\text { High } \mathrm{A}_{2 \mathrm{~A}} \mathrm{R} \text { expression in left atria [46,68]. } \\
\text { Reflex (neurohumoral) syncope } \\
\text { Vasovagal syncope }\end{array}$ \\
$\begin{array}{c}\text { Heterogenous expression of } \mathrm{A}_{1} \text { R in right atria [69] } \\
\text { Syncope without prodrome, normal heart and normal } \\
\text { electrocardiogram }\end{array}$ & $\begin{array}{c}\text { High APL [70] } \\
\text { High } \mathrm{A}_{2 \mathrm{~A}} \text { R expression [71,72] }\end{array}$ \\
CC variant in the second exon of the gene [72] \\
Low APL [73,74] \\
Low $\mathrm{A}_{2 \mathrm{~A}}$ R expression [73]
\end{tabular}


Table 1. Cont.

\begin{tabular}{cc}
\hline Disease & Purinergic Abnormalities \\
\hline Hypoxic conditions & High APL $[75,76]$ \\
\hline TLOC during dive & $\begin{array}{c}\text { High hypoxanthine and xanthine serum levels [77] } \\
\text { High APL and serum uric acid [78,79] }\end{array}$ \\
\hline Sleep apnea & High APL, high $\mathrm{A}_{2 \mathrm{~B}}$ R expression and low ENT1 [80] \\
\hline Altitude hypoxia & High APL [81] \\
\hline Hypertension conditions & High A2A expression [82] \\
\hline Systemic hypertension & Low APL in pulmonary arteries [83,84] \\
\hline Pulmonary Hypertension & CHF: High APL [85,86] \\
Heart failure & Increase in A $\mathrm{A}_{2 \mathrm{~A}} \mathrm{R}$ expression $[87]$ \\
\hline
\end{tabular}

\footnotetext{
APL: adenosine plasma level; $A_{1} R$ : adenosine $A_{1}$ receptor; $A_{2 A} R$ : adenosine $A_{2 A}$ receptor; $A_{2 B} R$ : adenosine $A_{2 B}$ receptor; AHF: acute heart failure. CHF: chronic heart failure. TLOC: transient loss of consciousness.
}

Adenosine may initiate AF through three main mechanisms: (i) Sympatho-excitatory effects; (ii) shortening the refractory period via the activation of the inward rectifying $\mathrm{K}+$ current $\left(\mathrm{IK}_{\mathrm{ado}}\right)$ [42]; and (iii) direct stimulation of the pulmonary vein tissue [61]. This last effect seems to be sufficient to trigger AF [61].

\subsection{Effects of Exogenous Adenosine}

Adenosine or ATP are commonly used to treat supraventricular tachycardia [89]. The side effects of exogenous adenosine include bronchospasm [90], chest pain [91], bradycardia, and sometimes complete AVB [92]. This effect may be used for the diagnosis of unexplained syncope (see below). Sometimes, the administration of exogenous adenosine has resulted in asystole followed by myoclonic jerk or death [93,94]. It seems that exogenous adenosine may cross the feto-placental barrier since fetal bradycardia was observed after adenosine administration for maternal supraventricular tachycardia [95]. Ventricular tachycardia or torsade de pointes have rarely been observed after adenosine administration [96-98]. By provoking transient bradycardia followed by sinus tachycardia, adenosine was shown in a single study on 18 cases and 20 controls to induce abnormal QT responses in patients with long QT syndrome (LQTS) compared to controls, suggesting that adenosine administration might be useful for distinguishing patients with LQTS from healthy controls [99]. However, this study was never replicated, and the "adenosine challenge test" is not actually considered part of the diagnostic worked out in cases of suspected LQTS. Torsade de pointes have also been observed after adenosine administration in patients with $[100,101]$ or without QT prolongation [98,102]. Most effects of exogenous adenosine administration are summarized in Table 2.

Table 2. Main effects on heart rhythm after exogenous adenosine administration.

\begin{tabular}{cc}
\hline & Interruption of tachycardia [89] \\
AVB [92] \\
AVB in low adenosine syncope patients [73,103] \\
Asystole, myoclonic jerk [93] \\
Fetal bradycardia [95] \\
Atrial fibrillation [60] \\
Atrial premature complex [62] \\
Atrial ectopic beats [63] \\
Flutter [62] \\
\hline Increased QT interval in LQTS [99] \\
Torsade de pointes in LQTS [100] \\
Ventricular tachycardia [96,97] \\
Torsade de pointes [98,102] \\
\hline
\end{tabular}

AVB: atrioventricular block; LQTS: long QT syndrome. 


\subsection{Adenosine and Reflex (Neurohumoral) Syncope}

Reflex (neurohumoral) syncopes (NHS) are frequent (1\%-3\%) in the general population and may severely alter the quality of life of patients. NHS is responsible for 3\% to $5 \%$ of emergency entrance and $1 \%$ to $2 \%$ of hospitalizations with a poor outcome in nearly $7 \%$ of cases $[104,105]$. NHS episodes occur at least once during life in $50 \%$ of the whole population. NHS is characterized by a partial (presyncope) or complete loss of consciousness due to a decrease in heart rate and systemic blood pressure in the absence of any heart structural abnormalities. Loss of consciousness is often preceded by prodromes, including discomfort, nausea, vomiting, abdominal pain, but sometimes the loss of consciousness occurs at outset, without or with very short prodromes $[73,74,103]$. Symptoms may be reproduced by the head up tilt test (HUT) [106] or sometimes by ATP or adenosine administration [107].

There is evidence that the adenosinergic system is implicated in the pathophysiology of NHS. Patients with typical vasovagal syncope (VVS) have a high baseline APL that further increases during HUT-induced syncope [70], high expression of $\mathrm{A}_{2 \mathrm{~A}} \mathrm{R}$ [71] and specific single nucleotide polymorphism (CC variant) in the second exon of the gene encoding the $\mathrm{A}_{2 \mathrm{~A}} \mathrm{R}$ [72]. Hyperoxia, which induces a drop in APL, restores hemodynamic status during HUT [108], thus suggesting that adenosine modifies the behavior of heart rate and blood pressure during HUT. In VVS, high APL stimulates low affinity $\mathrm{A}_{2 \mathrm{~A}} \mathrm{R}$ $\left(\mathrm{K}_{\mathrm{D}} 1.8 \mu \mathrm{M}\right)$ that causes vasodilation [30]. The high basal adenosine plasma level may be secondary to the high $\mathrm{A}_{2 \mathrm{~A}} \mathrm{R}$ expression, which could be itself secondary to a genetic predisposition, as documented by a specific polymorphism. Indeed, it was shown that activation of $A_{2 A} R$ produces an increase in ENT expression favoring the release of adenosine in extracellular spaces [109] and thus an increase in extracellular adenosine, creating a vicious circle (see Figure 3).

More recently, a low adenosine syncope subtype was described that is characterized clinically by the presence of short or no prodromes. In this kind of syncope, the loss of consciousness may be reproduced by ATP or adenosine administration $[73,74,103,110]$.

In low APL syncope, the adenosine concentration is under the affinity $\left(K_{\mathrm{D}}\right)$ value for the activation of $A_{1} R\left(K_{D} 0.8 \mu \mathrm{M}\right)$ [111]. Thus, a small increase in APL (due to transient hypoxia, beta-adrenergic stimulation, weak decrease in blood pressure or unnoticed inflammatory process) may lead to the activation of $A_{1} R$, creating a sinus arrest or an AV block, mostly via the activation of $I_{\text {Ado }}$ that induces hyperpolarization [25] (see Figure 2). In this case, the APL is sufficient to activate high affinity $A_{1} R$ but not low affinity $\mathrm{A}_{2 \mathrm{~A}} \mathrm{R}$, and thus, vasodilation is less important. In this subtype of syncope, the use of theophylline, a nonspecific adenosine receptor antagonist, is often effective in a preventive manner because theophylline binds to $\mathrm{A}_{1} \mathrm{R}$ and prevents adenosine binding $[75,112]$. Finally, if high APL plays a role in explaining VVS in patients, the cause of low APL in low adenosine syncope remains unknown. Abnormalities in adenosine metabolism, including ENT or ADA expression, which are currently under investigation, are potential factors.

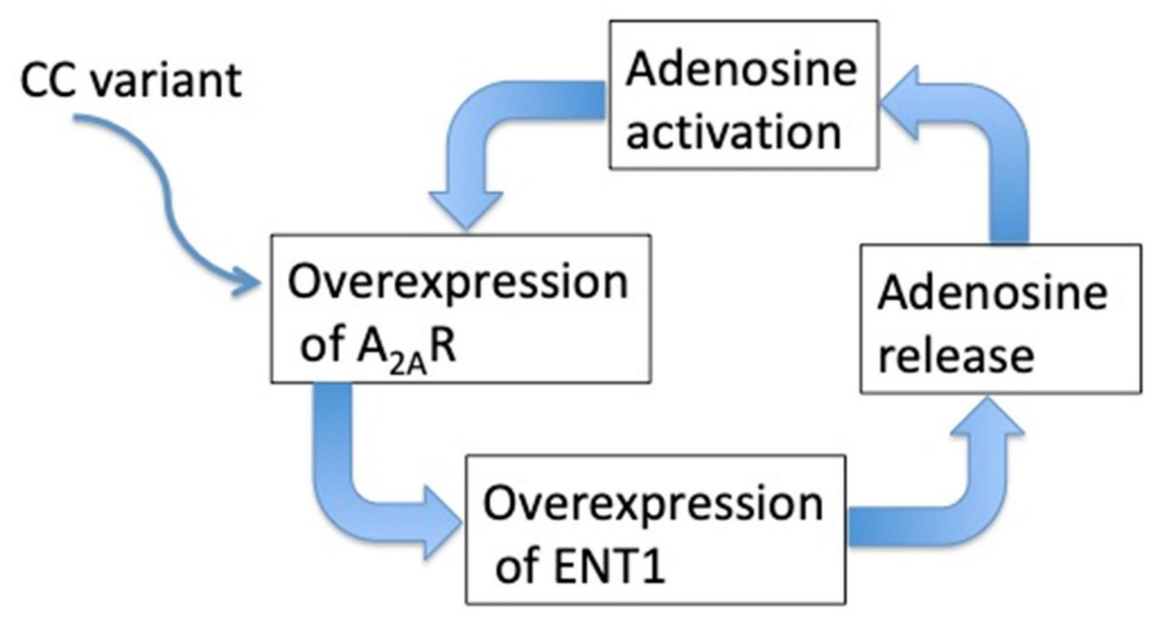

Figure 3. the vicious circle of adenosine release in vasovagal syncope. 


\subsection{Adenosine and Hypoxia}

\subsubsection{Syncope in Hypoxic Conditions}

During breath-hold diving, a transient loss of consciousness (TLOC) may occur, which is attributed to cerebral hypoxemia. Adenosine release, induced by hypoxia, may precipitate TLOC. Indeed, high APL was observed in basal conditions and further increased during breath-hold [76,113]. The adenosinergic profile of divers is different from that of patients with VVS since the HUT test was positive in only $16 \%$ of divers compared with $80 \%$ in patients with VVS [76]. The CC variant of the SNP was observed in the majority (56\%) of patients with VVS, whereas the TC variant was found in $56 \%$ of divers and $61 \%$ of divers who had previous TLOC during diving [76]. Heart rate and $\mathrm{O}_{2}$ saturation were both correlated with APL in breath-hold divers. Furthermore, divers with the highest APL at the end of breath-hold were the same ones who reported previous TLOC during diving [113]. In addition, hypercapnia occurs during breath-hold diving. Adenosine mediates the hypercapnic response in the rat carotid body via $\mathrm{A}_{2 \mathrm{~A}} \mathrm{R}$ and $\mathrm{A}_{2 \mathrm{~B}} \mathrm{R}$, which promotes bradycardia via the carotid sinus pathway [114]. In conclusion, we hypothesize that in some cases, TLOC may be secondary to severe bradycardia, sinus arrest or AVB in the context of high APL.

\subsubsection{Obstructive Sleep Apnea Syndrome}

Obstructive sleep apnea syndrome (OSAS) is characterized by episodes of partial or complete occlusion of upper airways during sleep, which is associated with hypoxemia. Sleep apnea is a serious condition that has been reported to affect more than 22 million Americans who suffer from a lack of restorative sleep. Typical symptoms of sleep apnea include heavy snoring, excessive daytime sleepiness or fatigue, difficulty with concentration or memory, and waking during the night feeling short of breath. Untreated sleep apnea can lead to serious health consequences, including chronic hypoxemia, systemic and pulmonary hypertension, and heart failure [115,116]. Hypoxemia occurs during sleep in OSAS. It was shown that adenosine plasma levels and its metabolites, including uric acid (see Figure 1), increase during apnea in patients with OSAS [77-79]. In most cells, hypoxia induces the stabilization of HIF (hypoxia-inducible factor) alpha subunit, which inhibits adenosine kinases, leading to the inhibition of rephosphorylation of adenosine in ATP and then favoring the accumulation of adenosine in both intra- and extracellular spaces [117]. The decrease in $\mathrm{PaO}_{2}$ and the lack of ATP also explain the increase in blood lactates during apnea [118]. In the brainstem, due to its hyperpolarizing properties on neurons, adenosine participates in the initiation of sleep. During wakefulness, adenosine levels gradually increase in areas of the brain that are important for promoting arousal, in particular the reticular activating system in the brainstem. The extracellular adenosine concentration increases during sleep. Therefore, high levels of adenosine cause sleep [119]. Caffeine, a nonspecific adenosine receptor antagonist, works to inhibit sleep by blocking the action of adenosine within the brain, which facilitates wakefulness. Finally, an $\mathrm{A}_{1} \mathrm{R}$ agonist (N (6)-p-sulfophenyladenosine) suppresses apnea during all sleep stages in rats, and this effect occurs via the peripheral nervous system [120]. In summary, adenosine during sleep apnea is released in response to hypoxia and may promote sleep but inhibits apnea episodes through $\mathrm{A}_{1} \mathrm{R}$ activation.

\subsubsection{Altitude Hypoxia}

Physiological adaptation to hypoxia is a source of intensive investigations. In daily life, hypoxia may be due to reduced barometric pressure, as in altitude-induced hypoxia conditions, while in pathophysiological conditions, hypoxia may be secondary to pulmonary obstructive or restrictive disease. Hypoxia may also be acute or chronic depending on the cause of hypoxia and the features of the responsible disease. Unlike sleep apnea or breath-holding, altitude hypoxia is not associated with hypercapnia and acidosis. Thus, hypercapnia-induced $\mathrm{A}_{2} \mathrm{R}$ stimulation in carotid glomus cells lacking at altitude. In all cases, however, the extracellular accumulation of adenosine is a crucial protective step to limit cellular damage during hypoxia [1,121]. Hypoxia leads to an increase 
in adenosine extracellular concentration [1], which favors vasodilation through the activation of adenosine $A_{2 A}$ and $A_{2 B}$ receptors $[122,123]$. Short exposure $(3 \mathrm{~h})$ to low $\mathrm{PO}_{2}$ increases the mRNA and protein of the $A_{2 B}$ receptor subtype independently of the HIF pathway [123]; chemical hypoxia also upregulates $\mathrm{A}_{2 \mathrm{~A}} \mathrm{R}$ expression via the NF-kappa $\mathrm{B}$ pathway [124]. It is unclear why acute altitude induces simultaneous pulmonary vasoconstriction and peripheral vasodilation. The latter, however, after $6-8 \mathrm{~h}$, is overwhelmed by reflex vasoconstriction due to sympathetic activation by chemoreflex stimulation and endothelial dysfunction related to oxidative stress.

The extracellular concentration of adenosine during hypoxia is mainly controlled by ADA [1] and by ENT-1 $[10,11,125]$ with the expression of ENT-1 being mainly controlled by $\mathrm{A}_{2 \mathrm{~B}} \mathrm{R}$ in erythrocytes [126] and HIF in human dermal microvascular endothelium and in endothelium from the human saphenous vein [125]. High altitude exposure is a well-known cause of hypoxia due to reduced partial oxygen pressure in the alveolar air-hypobaria. In these conditions, an increase in the adenosine extracellular level was observed, which was attributed to both an increase in CD73 activity [126], leading to the increase in dephosphorylation of ATP into 5' AMP and a decrease in ENT-1 erythrocyte expression [80], leading to the inhibition of adenosine uptake by erythrocytes (see Figure 1). It was found that an increase in APL via activation of $\mathrm{A}_{2 \mathrm{~B}} \mathrm{R}$ induced downregulation of the ENT1 transporter in erythrocytes, which participates in faster acclimatization to high altitude upon re-ascent [80]. Furthermore, adenosine via $A_{2 B}$ induces the production of 2,3-BPG by erythrocytes after only a few hours of hypoxia exposure [126]. 2,3-BPG favors $\mathrm{O}_{2}$ liberation by hemoglobin in an allosteric manner. The adenosine pathway also impacts erythrocyte glucose metabolism, favoring more $\mathrm{O}_{2}$ delivery during adaptive mechanisms to high altitude-induced hypoxia [127]. Altitude hypoxia also seems to modify platelet reactivity through the purinergic pathway. Indeed, hypobaric hypoxia significantly reduced the ability of a fixed concentration of cangrelor to inhibit ADP-induced aggregation and increased basal vasodilator-stimulated phosphoprotein (VASP) phosphorylation [128]. In summary, the adenosinergic response seems to be a crucial adaptative response to altitude hypoxia.

\subsection{Myocardial Ischemia Reperfusion Protection}

The contribution of adenosine to the regulation of coronary blood flow was first postulated by Berne [31]. Adenosine is known to induce vasodilation, via $A_{2 A} R$ and $A_{2 B} R$ [26,30,37], leading to an increase in blood flow and oxygenation. While it was established that adenosine is not required for the regulation of $\mathrm{CBF}$ at rest, its contribution is crucial during effort when myocardial oxygen requirements are not sufficiently met or during ischemia process $[129,130]$. The contribution of $A_{2 A} R$ and $A_{2 B} R$ to coronary vasodilation is particularly marked in the adaptive response to ischemia process. Adenosine accumulates during hypoxia or ischemia, due to the imbalance between $\mathrm{O}_{2}$ supply and need resulting in an imbalance between ATP synthesis and consumption [131]. Interstitial adenosine concentration increase during ischemia but decrease with repetitive brief ischemia [132,133]. The administration of exogenous adenosine reduced infarct size in an animal model of myocardial ischemia [134].

Cardioprotection seems to involve $A_{1} R[135-137]$ and $A_{3} R[135,138]$ through a proteine kinase $C, K_{\text {ATP }}$ channels and antiadrenergic effects [139]. Over expression of $A_{1} R$ is associated with increased resistance to ischemia, while the precise mechanism of $A_{3} R$-induced cardioprotection remains elusive [138].

In a clinical point of view, adenosine plasma was found to be high in the coronary sinus of patients with severe coronary artery disease that decreased after percutaneous transluminal angioplasty (PTCA) [140]. The use of dipyridamole that increases extracellular adenosine concentration improved tolerance during exercise stress test [141]. Intra coronary adenosine administration may also be beneficial during PTCA by improving ischemia reperfusion injuries, left ventricular farction ejection and by improving clinical outcome $[142,143]$ and by while its administration improver. Exogenous adenosine is used commonly in patients with coronary artery disease to determine coronary reserve, to induce a maldistribution and to image such maldistribution [144]. 
Thus the release of endogenous adenosine during ischemia seems to be an adaptive mechanism to improve coronary blood flow.

\subsection{Adenosine and Vascular Injury and Repair}

Adenosine also plays a major role in promoting wound healing and vascular tissues repair [145]. Thus $\mathrm{A}_{2}$ adenosine receptor subtypes are required to new matrix production and angiogenesis while $A_{1} R$ up regulates vascular endothelial growth factor from monocytes and contributes to new vessels formation [146]. The activation of adenosine receptors promotes endothelial cell proliferation and stimulates angiogenesis factors production. In this context, activation of $A_{2 A} R$ promotes wound healing during experimental tissue injury [147].

Vascular muscle cell proliferation is an important component of vascular remodeling which is regulated partly through $\mathrm{A}_{2 \mathrm{~B}}$ receptors [148] and it was shown that activation of $\mathrm{A}_{2 \mathrm{~B}} \mathrm{R}$ protects against vascular injury [149].

Finally drugs that increase adenosine plasma levels, improved endothelial function [150]. Thus targeting $\mathrm{A}_{2 \mathrm{~A}}$ and $\mathrm{A}_{2 \mathrm{~B}}$ receptors are promising for vascular healing after injury [151,152].

\subsection{Adenosine and Systemic Hypertension}

The adenosinergic system plays a major role in the control of heart rate and blood pressure. Adenosine inhibits alpha-1 adrenoreceptor responses in physiological and pathophysiological conditions $[153,154] . \mathrm{A}_{2 \mathrm{~A}} \mathrm{R}$ and $\mathrm{A}_{2 \mathrm{~B}} \mathrm{R}$ are expressed in myocytes of arteries including large arterial trunks [17], while $A_{1} R$ are expressed in the renal microcirculation [155], where they promote renal vasoconstriction, mediate tubuloglomerular feedback [156], and augment renal vasoconstriction induced by angiotensin-II $[157,158]$ and norepinephrine [155]. $\mathrm{A}_{1} \mathrm{R}$ antagonists increase sodium excretion in rats [159], and $A_{1} R$ activation leads to vasoconstriction in the aorta and mesenteric arteries $[160,161]$ and sodium reabsorption in the kidney $[82,159]$.

$\mathrm{A}_{2 \mathrm{~A}} \mathrm{R}$ mediates vasodilation in most arteries, including the aorta [17,33], kidney arteries [81], and skeletal muscles [162], and promotes natriuresis via the increase in blood flow in renal medulla vessels $[157,163]$. $A_{2 B}$ mediates vasodilation in most arteries, including the aorta [164], and mesenteric arteries [165]. In the renal medullary circulation, both $A_{2 A}$ and $A_{2 B} R$ regulate blood pressure by increasing blood flow and thus enhancing sodium excretion [166]. However, $A_{2 B} R$ may promote kidney fibrosis through the production of endothelin 1, thus promoting chronic hypertension [167].

An overexpression of $\mathrm{A}_{2 \mathrm{~A}} \mathrm{R}$ was described on lymphocytes of patients suffering from essential hypertension, which normalized after alpha 1 blockade but not after administration of beta blocking agents [168]. The increase in $\mathrm{A}_{2 \mathrm{~A}} \mathrm{R}$ expression associated with the increase in the affinity of receptors may be a compensatory mechanism aimed at increasing vasodilation to compensate for high blood pressure. Recently, it was shown that adenosine receptors influence hypertension in Dahl salt-sensitive rats and that this influence depends on sex. Indeed, beneficial effects of $A_{1} R$ or $A_{2 B} R K O$ were limited to females [155]. High APL was found in patients with essential hypertension [169], while high $A_{2 B}$ receptor expression was found in patients with hypertension associated with fibromuscular dysplasia [169].

$\mathrm{A}_{3} \mathrm{R}$ also participates in the regulation of blood pressure by affecting the steady-state level of cAMP in smooth muscle cells [23].

In summary, due to its impact on vasodilation, heart rate, and sodium excretion regulation, the adenosinergic system strongly impacts blood pressure regulation. In this perspective the use of specific $A_{2 A} R$ agonists or $A_{1} R$ antagonists to lower blood pressure should be promising.

\subsection{Adenosine and Pulmonary Hypertension}

Primary pulmonary hypertension (PAH) is a severe disease associated with a high incidence of death $[83,170]$ and is characterized by elevation in pulmonary artery pressure followed by right ventricular hypertrophy. The pathophysiology of this condition remains unclear, and PAH seems to 
be of multifactorial origin. Acute altitude exposure is associated with increased pulmonary pressure (involving endothelin 1 receptor activation) [84]. Sometimes, chronic high altitude exposure may also promote pulmonary hypertension [171].

Dysfunction of endothelial and smooth cells seems to play a major role [172]. Dysregulation of the renin-angiotensin-aldosterone system has also been advocated [85]. Experimental data seem to indicate that adenosine may be a potential endogenous regulator of PAH development by regulating smooth muscle proliferation and vasodilator properties. Adenosine via $\mathrm{A}_{2 \mathrm{~A}} \mathrm{R}$ exerts vasodilation in pulmonary circulation since the lack of adenosine $\mathrm{A}_{2 \mathrm{~A}} \mathrm{R}$ confers pulmonary arterial hypertension in mice [86], while in situ adenosine infusion reduced pulmonary vascular resistance in humans [88]. Furthermore, $\mathrm{A}_{2 \mathrm{~A}} \mathrm{R}$ agonist attenuates the progression of pulmonary hypertension in an experimental model of PAH [173]. Endogenous adenosine measured in distal pulmonary arteries was found to be lower in PAH than in controls $[174,175]$. Thus, the low APL in the pulmonary arteries may participate in the high pulmonary vascular resistance (PVR) in PAH. This fact is supported by the correlation between APL and PVR [174]. Activation of $\mathrm{A}_{2 \mathrm{~A}} \mathrm{R}$ leads to strong vasodilation via pulmonary endothelial $\mathrm{NO}$ synthesis, smooth cell hyperpolarization and inhibition of collagen deposition [173]. Thus, targeting $\mathrm{A}_{2 \mathrm{~A}} \mathrm{R}$ could potentially serve as an efficient treatment of $\mathrm{PAH}$, especially since there is, currently, no convincing treatment available.

\subsection{Adenosine and Heart Failure}

Acute heart failure (AHF) and chronic heart failure (CHF) are the most common complications of cardiovascular disease. The prevalence of HF depends on the definition applied, but it is approximately $1 \%-2 \%$ of the adult population in developed countries, rising to $\geq 10 \%$ among people $>70$ years of age [87].

CHF results in the release of many neurohumoral factors, including catecholamines, renin angiotensin, and cytokines. While a number of cytokines worsen cardiac performance [176], some of them, like adenosine, may have protective effects.

High APL has been measured in both AHF and CHF $[87,88,173-179]$ and was attributed to cardiac failure-induced hypoxemia and to a downregulation of adenosine deaminase [178-180].

$\mathrm{A}_{1} \mathrm{R}$ KO mice exhibit a normal cardiac phenotype in the absence of stress, while overexpression of $\mathrm{A}_{1} \mathrm{R}$ leads to an increase in myocardium protection against ischemia [181]. This effect was attributed to the inhibition of calcium overload in the sarcoplasmic reticulum that occurs during ischemia [182].

$\mathrm{A}_{2 \mathrm{~A}} \mathrm{R}$ gene expression was found to be increased in patients with dilated cardiomyopathy and in patients with terminal CHF who normalized after transplantation [183]. $\mathrm{A}_{2 \mathrm{~A}} \mathrm{R}$ deletion also leads to cytokine release and proinflammatory effects, yet cytokine release participates in the pathophysiology of CHF [184]. $\mathrm{A}_{2 \mathrm{~A}} \mathrm{R}$ activation also leads to inotropic effects [19,20]. Finally, a polymorphism (SNP rs4822489) was found to be associated with the severity of CHF [185].

In AHF, high APL and high $\mathrm{A}_{2 \mathrm{~A}} \mathrm{R}$ expression have been observed [179]. Adenosine release is secondary to tissue hypoxemia, and the activation of $\mathrm{A}_{2 \mathrm{~A}} \mathrm{R}$ may be beneficial by promoting inotropic function. In cardiogenic shock, $\mathrm{A}_{2 \mathrm{~A}} \mathrm{R}$ expression was lower than in AHF. In AHF, the priority may be to restore myocardium function by increasing both APL and $\mathrm{A}_{2 \mathrm{~A}} \mathrm{R}$ expression, while in cardiogenic shock, the priority may be to restore a sufficient blood pressure level by decreasing $A_{2 A} R$ expression leading to vasoconstriction [179].

Regarding $\mathrm{A}_{2 \mathrm{~B}} \mathrm{R}$, it was shown that its inhibition reduces left ventricular dysfunction and ventricular arrhythmias after experimental myocardial ischemia [186]. Regarding $A_{3} R$, its deficiency exerts protective effects on pressure-overload-induced left ventricular hypertrophy and dysfunction [187].

In summary, by impacting vascular tone, myocardial inotropy and sodium excretion, the adenosinergic system appears to be an important modulator in heart failure. 


\section{Conclusions and Future Directions}

The adenosinergic system appears to have a key role in the adaptive response of the cardiovascular system both in physiological and pathophysiological conditions.

Adenosine release is likely to participate in the pathophysiology of the disease in at least two conditions, namely, atrial fibrillation and some forms of reflex (neurohumoral) syncope. The adenosinergic system appears to have a key role in the adaptive response of the cardiovascular system in pulmonary hypertension and heart failure, the most relevant effects being slowing of heart rhythm, coronary vasodilation, and decreasing blood pressure. Finally, in other cases, such as altitude or apnea-induced hypoxia, obstructive sleep apnea, and systemic hypertension, adenosine is rather a consequence of the disease in the context of an adaptive response.

Due to its metabolism and quick release, adenosine, via the activation of its receptors, allows very rapid adaptation of the cardiovascular system, with opposite effects to those of the catecholaminergic system. Owing to the complex interaction of adenosine with cardiovascular pathophysiology, the effects of adenosine on the cardiovascular system are sometimes beneficial and sometimes harmful. Future research should aim to develop modulating agents of adenosine receptors to slow down or conversely amplify the adenosinergic response according to the occurrence of different pathologic conditions.

Author Contributions: R.G.: fundamental part of the manuscript (i.e., adenosine metabolism and receptors); B.M., M.B., J.-C.D., and L.C.: arrhythmia part of the manuscript; G.P.: hypoxia, heart failure and hypertension part of the manuscript; E.T.: critical reading of the manuscript; All of the authors substantially contributed to further literature review, discussions of the content, and reviewed and edited the manuscript before submission. All authors have read and approved the present version. All authors have read and agreed to the published version of the manuscript.

Funding: This work was supported by Aix Marseille University.

Conflicts of Interest: The authors declare no conflict of interest.

\section{References}

1. $\quad$ Eltzschig, H.K.; Faigle, M.; Knapp, S.; Karhausen, J.; Ibla, J.; Rosenberger, P.; Odegard, K.C.; Laussen, P.C.; Thompson, L.F.; Colgan, S.P. Endothelial catabolism of extracellular adenosine during hypoxia: The role of surface adenosine deaminase and CD26. Blood 2006, 108, 1602-1610. [CrossRef] [PubMed]

2. Grenz, A.; Homann, D.; Eltzschig, H.K. Extracellular Adenosine: A Safety Signal That Dampens Hypoxia-Induced Inflammation During Ischemia. Antioxidants Redox Signal. 2011, 15, 2221-2234. [CrossRef] [PubMed]

3. Le, G.; Essackjee, H.; Ballard, H. Intracellular adenosine formation and release by freshly-isolated vascular endothelial cells from rat skeletal muscle: Effects of hypoxia and/or acidosis. Biochem. Biophys. Res. Commun. 2014, 450, 93-98. [CrossRef] [PubMed]

4. Idzko, M.; Ferrari, D.; Eltzschig, H.K. Nucleotide signalling during inflammation. Nature 2014, 509, 310-317. [CrossRef]

5. Sumi, Y.; Woehrle, T.; Chen, Y.; Yao, Y.; Li, A.; Junger, W.G. Adrenergic receptor activation involves ATP release and feedback through purinergic receptors. Am. J. Physiol. Physiol. 2010, 299, C1118-C1126. [CrossRef]

6. Fredholm, B.B.; Ijzerman, A.P.; Jacobson, K.A.; Linden, J.; Müller, C.E. International Union of Basic and Clinical Pharmacology. LXXXI. Nomenclature and classification of adenosine receptors-An update. Pharmacol. Rev. 2011, 63, 1-34. [CrossRef]

7. Burnstock, G. Purinergic Signaling in the Cardiovascular System. Circ. Res. 2017, 120, 207-228. [CrossRef]

8. Borea, P.A.; Gessi, S.; Merighi, S.; Vincenzi, F.; Varani, K. Pharmacology of Adenosine Receptors: The State of the Art. Physiol. Rev. 2018, 98, 1591-1625. [CrossRef]

9. Onyedibe, K.I.; Wang, M.; Sintim, H.O. ENPP1, an Old Enzyme with New Functions, and Small Molecule Inhibitors-A STING in the Tale of ENPP1. Molecules 2019, 24, 4192. [CrossRef]

10. Plagemann, P.G.W.; Wohlhueter, R.M.; Kraupp, M. Adenosine uptake, transport, and metabolism in human erythrocytes. J. Cell. Physiol. 1985, 125, 330-336. [CrossRef]

11. Pastor-Anglada, M.; Pérez-Torras, S. Who Is Who in Adenosine Transport. Front. Pharmacol. 2018, 9, 627. [CrossRef] [PubMed] 
12. Idzko, M.; Ferrari, D.; Riegel, A.-K.; Eltzschig, H.K. Extracellular nucleotide and nucleoside signaling in vascular and blood disease. Blood 2014, 124, 1029-1037. [CrossRef] [PubMed]

13. Shryock, J.C.; Belardinelli, L. Adenosine and Adenosine Receptors in the Cardiovascular System: Biochemistry, Physiology, and Pharmacology. Am. J. Cardiol. 1997, 79, 2-10. [CrossRef]

14. Headrick, J.P.; Ashton, K.J.; Rose'Meyer, R.B.; Peart, J.N. Cardiovascular adenosine receptors: Expression, actions and interactions. Pharmacol. Ther. 2013, 140, 92-111. [CrossRef]

15. Musser, B.; E Morgan, M.; Leid, M.; Murray, T.F.; Linden, J.; E Vestal, R. Species comparison of adenosine and beta-adrenoceptors in mammalian atrial and ventricular myocardium. Eur. J. Pharmacol. 1993, 246, 105-111. [CrossRef]

16. Hussain, T.; Mustafa, S.J. Binding of A1Adenosine Receptor Ligand [3H]8-Cyclopentyl-1,3-Dipropylxanthine in Coronary Smooth Muscle. Circ. Res. 1995, 77, 194-198. [CrossRef]

17. Iwamoto, T.; Umemura, S.; Toya, Y.; Uchibori, T.; Kogi, K.; Takagi, N.; Ishii, M. Identification of Adenosine A2 Receptor-cAMP System in Human Aortic Endothelial Cells. Biochem. Biophys. Res. Commun. 1994, 199, 905-910. [CrossRef]

18. Marala, R.B.; Mustafa, S.J. Immunological characterization of adenosine A2A receptors in human and porcine cardiovascular tissues. J. Pharmacol. Exp. Ther. 1998, 286, 1051-1057.

19. Monahan, T.S.; Sawmiller, D.R.; Fenton, R.A.; Dobson, J.G. Adenosine A(2a)-receptor activation increases contractility in isolated perfused hearts. Am. J. Physiol. Circ. Physiol. 2000, 279, H1472-H1481. [CrossRef]

20. Dobson, J.G., Jr.; Fenton, R.A. Adenosine A2 receptor function in rat ventricularmyocytes. Cardiovasc. Res. 1997, 34, 337-347. [CrossRef]

21. Morrison, R.R.; Talukder, M.A.H.; Ledent, C.; Mustafa, S.J. Cardiac effects of adenosine in A2A receptor knockout hearts: Uncovering A2B receptors. Am. J. Physiol. Circ. Physiol. 2002, 282, H437-H444. [CrossRef] [PubMed]

22. Son, Y.K.; Park, W.S.; Ko, J.-H.; Han, J.; Kim, N.; E Earm, Y. Protein kinase A-dependent activation of inward rectifier potassium channels by adenosine in rabbit coronary smooth muscle cells. Biochem. Biophys. Res. Commun. 2005, 337, 1145-1152. [CrossRef] [PubMed]

23. Zhao, Z.; Francis, C.E.; Ravid, K. An A3-Subtype Adenosine Receptor Is Highly Expressed in Rat Vascular Smooth Muscle Cells: Its Role in Attenuating Adenosine-Induced Increase in cAMP. Microvasc. Res. 1997, 54, 243-252. [CrossRef] [PubMed]

24. Zhao, Z.; Makaritsis, K.; E Francis, C.; Gavras, H.; Ravid, K. A role for the A3 adenosine receptor in determining tissue levels of cAMP and blood pressure: Studies in knock-out mice. Biochim. Biophys. Acta (BBA) Bioenerg. 2000, 1500, 280-290. [CrossRef]

25. Belardinelli, L.; Shryock, J.C.; Song, Y.; Wang, D.; Srinivas, M. Ionic basis of the electrophysiological actions of adenosine on cardiomyocytes. FASEB J. 1995, 9, 359-365. [CrossRef]

26. Sanjani, M.S.; Teng, B.; Krahn, T.; Tilley, S.; Ledent, C.; Mustafa, J.S. Contributions of A2A and A2B adenosine receptors in coronary flow responses in relation to the KATP channel using A2B and A2A/2B double-knockout mice. Am. J. Physiol. Circ. Physiol. 2011, 301, H2322-H2333. [CrossRef]

27. Ledent, C.; Vaugeois, J.-M.; Schiffmann, S.N.; Pedrazzini, T.; El Yacoubi, M.; Vanderhaeghen, J.-J.; Costentin, J.; Heath, J.; Vassart, G.; Parmentier, M. Aggressiveness, hypoalgesia and high blood pressure in mice lacking the adenosine A2a receptor. Nature 1997, 388, 674-678. [CrossRef]

28. Wolska, N.; Rozalski, M. Blood Platelet Adenosine Receptors as Potential Targets for Anti-Platelet Therapy. Int. J. Mol. Sci. 2019, 20, 5475. [CrossRef]

29. Fenouillet, E.; Mottola, G.; Kipson, N.; Paganelli, F.; Guieu, R.; Ruf, J. Adenosine Receptor Profiling Reveals an Association between the Presence of Spare Receptors and Cardiovascular Disorders. Int. J. Mol. Sci. 2019, 20, 5964. [CrossRef]

30. Shryock, J.C.; Snowdy, S.; Baraldi, P.G.; Cacciari, B.; Spalluto, G.; Monopoli, A.; Ongini, E.; Baker, S.P.; Belardinelli, L. A2A-adenosine receptor reserve for coronary vasodilation. Circulation 1998, 98, 711-718. [CrossRef]

31. Berne, R.M. Cardiac nucleotides in hypoxia: Possible role in regulation ofcoronary blood flow. Am. J. Physiol. 1963, 204, 317-322. [CrossRef] [PubMed]

32. Mubagwa, K.; Mullane, K.; Flameng, W. Role of adenosine in the heart and circulation. Cardiovasc. Res. 1996, 32, 797-813. [CrossRef] 
33. Ponnoth, D.S.; Sanjani, M.S.; Ledent, C.; Roush, K.; Krahn, T.; Mustafa, S.J. Absence of adenosine-mediated aortic relaxation in A(2A) adenosine receptor knockout mice. Am. J. Physiol. Circ. Physiol. 2009, 297, H1655-H1660. [CrossRef] [PubMed]

34. Kusano, Y.; Echeverry, G.; Miękisiak, G.; Kulik, T.B.; Aronhime, S.N.; Chen, J.F.; Winn, H.R. Role of Adenosine A2 Receptors in Regulation of Cerebral Blood Flow during Induced Hypotension. Br. J. Pharmacol. 2009, 30, 808-815. [CrossRef] [PubMed]

35. Arsyad, A.; Dobson, G.P. Adenosine relaxation in isolated rat aortic rings and possible roles of smooth muscle Kv channels, KATP channels and A2a receptors. BMC Pharmacol. Toxicol. 2016, 17, 23. [CrossRef] [PubMed]

36. Kleppisch, T.; Nelson, M.T. Adenosine activates ATP-sensitive potassium channels in arterial myocytes via A2 receptors and cAMP-dependent protein kinase. Proc. Natl. Acad. Sci. USA 1995, 92, 12441-12445. [CrossRef]

37. Berwick, Z.C.; A Payne, G.; Lynch, B.; Dick, G.; Sturek, M.; Tune, J.D. Contribution of adenosine A(2A) and $\mathrm{A}(2 \mathrm{~B})$ receptors to ischemic coronary dilation: Role of $\mathrm{K}(\mathrm{V})$ and $\mathrm{K}(\mathrm{ATP})$ channels. Microcirculation 2010, 17, 600-607. [CrossRef]

38. Pelleg, A.; Hurt, C.; Miyagawa, A.; Michelson, E.L.; Dreifus, L.S. Differential sensitivity of cardiac pacemakers to exogenous adenosine in vivo. Am. J. Physiol. Circ. Physiol. 1990, 258, H1815-H1822. [CrossRef]

39. Mustafa, S.J.; Morrison, R.R.; Teng, B.; Pelleg, A. Adenosine Receptors and the Heart: Role in Regulation of Coronary Blood Flow and Cardiac Electrophysiology. Handb. Exp. Pharmacol. 2009, 193, 161-188. [CrossRef]

40. Belardinelli, L.; Giles, W.R.; West, A. Ionic mechanisms of adenosine actions in pacemaker cells from rabbit heart. J. Physiol. 1988, 405, 615-633. [CrossRef]

41. DiFrancesco, D.; Borer, J.S. The funny current: Cellular basis for the control of heart rate. Drugs 2007, 67, 15-24. [CrossRef] [PubMed]

42. Belardinelli, L. Modulation of atrioventricular transmission by adenosine. Prog. Clin. Boil. Res. 1987, 230, 109-118.

43. Pelleg, A.; Hurt, C.M.; Hewlett, E.L. ATP shortens atrial action potential duration in the dog: Role of adenosine, the vagus nerve, and G protein. Can. J. Physiol. Pharmacol. 1996, 74, 15-22. [CrossRef] [PubMed]

44. Gauthier, N.S.; Headrick, J.P.; Matherne, G.P. Myocardial function in the working mouse heart overexpressing cardiac A1 adenosine receptors. J. Mol. Cell. Cardiol. 1998, 30, 187-193. [CrossRef] [PubMed]

45. Neumann, J.; Boknik, P.; Begrow, F.; Hanske, G.; Justus, I.; Mat'Us, M.; Reinke, U.; Matherne, G.P.; Schmitz, W. Altered signal transduction in cardiac ventricle overexpressing $\mathrm{A}(1)$-adenosine receptors. Cardiovasc. Res. 2003, 60, 529-537. [CrossRef] [PubMed]

46. Hove-Madsen, L.; Prat-Vidal, C.; Llach, A.; Ciruela, F.; Casadó, V.; Lluís, C.; Bayés-Genís, A.; Cinca, J.; Franco, R. Adenosine A2A receptors are expressed in human atrial myocytes and modulate spontaneous sarcoplasmic reticulum calcium release. Cardiovasc. Res. 2006, 72, 292-302. [CrossRef]

47. Belardinelli, L.; Isenberg, G. Actions of adenosine and isoproterenol on isolated mammalian ventricular myocytes. Circ. Res. 1983, 53, 287-297. [CrossRef]

48. Song, Y.; Thedford, S.; Lerman, B.B.; Belardinelli, L. Adenosine-sensitive afterdepolarizations and triggered activity in guinea pig ventricular myocytes. Circ. Res. 1992, 70, 743-753. [CrossRef]

49. Xu, J.; Hurt, C.M.; Pelleg, A. Digoxin-induced ventricular arrhythmias in the guinea pig heart in vivo: Evidence for a role of endogenous catecholamines in the genesis of delayed. Heart Vessel. 1995, 10, 119-127. [CrossRef]

50. Song, Y.; Shryock, J.C.; Knot, H.J.; Belardinelli, L. Selective attenuation by adenosine of arrhythmogenic action of isoproterenol on ventricular myocytes. Am J Physiol. Heart. Circ. Physiol. 2001, 280, H2789-H2795. [CrossRef]

51. Zulkifly, H.; Lip, G.Y.H.; A Lane, D. Epidemiology of atrial fibrillation. Int. J. Clin. Pr. 2018, 72, e13070. [CrossRef] [PubMed]

52. Wijffels, M.C.; Kirchhof, C.J.; Dorland, R.A.; Allessie, M. Atrial fibrillation begets atrial fibrillation. A study in awake chronically instrumented goats. Circulation 1995, 92, 1954-1968. [CrossRef] [PubMed]

53. Carnagarin, R.; Kiuchi, M.G.; Ho, J.K.; Matthews, V.B.; Schlaich, M.P. Sympathetic Nervous System Activation and Its Modulation: Role in Atrial Fibrillation. Front. Mol. Neurosci. 2019, 12, 1058. [CrossRef] [PubMed]

54. Shen, M.J.; Zipes, U.P. Role of the Autonomic Nervous System in Modulating Cardiac Arrhythmias. Circ. Res. 2014, 114, 1004-1021. [CrossRef] [PubMed] 
55. Chen, S.-A.; Hsieh, M.H.; Tai, C.-T.; Tsai, C.F.; Prakash, V.S.; Yu, W.C.; Hsu, T.L.; A Ding, Y.; Chang, M.S. Initiation of atrial fibrillation by ectopic beats originating from the pulmonary veins: Electrophysiological characteristics, pharmacological responses, and effects of radiofrequency ablation. Circulation 1999, 100, 1879-1886. [CrossRef]

56. Haïssaguerre, M.; Jaïs, P.; Shah, D.C.; Takahashi, A.; Hocini, M.; Quiniou, G.; Garrigue, S.; Le Mouroux, A.; Le Metayer, P.; Clémenty, J. Spontaneous Initiation of Atrial Fibrillation by Ectopic Beats Originating in the Pulmonary Veins. N. Engl. J. Med. 1998, 339, 659-666. [CrossRef]

57. Haïssaguerre, M.; Jaïs, P.; Shah, D.C.; Gencel, L.; Pradeau, V.; Garrigues, S.; Chouairi, S.; Hocini, M.; Métayer, P.; Roudaut, R.; et al. Right and Left Atrial Radiofrequency Catheter Therapy of Paroxysmal Atrial Fibrillation. J. Cardiovasc. Electrophysiol. 1996, 7, 1132-1144. [CrossRef]

58. Lustgarten, D.L.; Keane, D.; Ruskin, J. Cryothermal ablation: Mechanism of tissue injury and current experience in the treatment of tachyarrhythmias. Prog. Cardiovasc. Dis. 1999, 41, 481-498. [CrossRef]

59. Ücer, E.; Fredersdorf, S.; Seegers, J.; Poschenrieder, F.; Hauck, C.; Maier, L.; Jungbauer, C. High Predictive Value of Adenosine Provocation in Predicting Atrial Fibrillation Recurrence After Pulmonary Vein Isolation With Visually Guided Laser Balloon Compared With Radiofrequency Ablation. Circ. J. 2020, 84, 404-410. [CrossRef]

60. Pelleg, A.; Pennock, R.S.; Kutalek, S.P. Proarrhythmic effects of adenosine: One decade of clinical data. Am. J. Ther. 2002, 9, 141-147. [CrossRef]

61. Ip, J.E.; Cheung, J.W.; Chung, J.H.; Liu, C.F.; Thomas, G.; Markowitz, S.M.; Lerman, B.B. Adenosine-Induced Atrial Fibrillation. Circ. Arrhythmia Electrophysiol. 2013, 6, 3. [CrossRef] [PubMed]

62. Strickberger, S.A.; Man, K.C.; Daoud, E.G.; Goyal, R.; Brinkman, K.; Knight, B.P.; Weiss, R.; Bahu, M.; Morady, F. Adenosine-induced atrial arrhythmia: A prospective analysis. Ann. Intern. Med. 1997, 127, 417-422. [CrossRef] [PubMed]

63. Isa-Param, R.; Pérez-Castellano, N.; Villacastín, J.; Moreno, J.; Salinas, J.; Alonso, R.; Ruiz, E.; Doblado, M.; Morales, R.; Macaya, C. [Inducibility of atrial arrhythmias after adenosine and isoproterenol infusion in patients referred for atrial fibrillation ablation]. Revista Española de Cardiología 2006, 59, 559-566. [CrossRef] [PubMed]

64. Maille, B.; Marlinge, M.; Vairo, D.; Mottola, G.; Koutbi, L.; Deharo, P.; Gastaldi, M.; Gaudry, M.; Guiol, C.; Bottone, S.; et al. Adenosine plasma level in patients with paroxysmal or persistent atrial fibrillation and normal heart during ablation procedure and/or cardioversion. Purinergic Signal. 2018, 15, 45-52. [CrossRef] [PubMed]

65. Lin, W.-D.; Deng, H.; Guo, P.; Liu, F.-Z.; Chen, R.-Y.; Fang, X.-H.; Zhan, X.-Z.; Liao, H.-T.; Huang, W.-X.; Liu, Y.; et al. High prevalence of hyperuricaemia and its impact on non-valvular atrial fibrillation: The crosssectional Guangzhou (China) Heart Study. BMJ Open 2019, 9, e028007. [CrossRef] [PubMed]

66. Deng, H.; Guo, P.; Zheng, M.; Huang, J.; Xue, Y.; Zhan, X.; Wang, F.; Liu, Y.; Fang, X.; Liao, H.; et al. Epidemiological Characteristics of Atrial Fibrillation in Southern China: Results from the Guangzhou Heart Study. Sci. Rep. 2018, 8, 17829. [CrossRef]

67. Kawasoe, S.; Kubozono, T.; Yoshifuku, S.; Ojima, S.; Miyata, M.; Miyahara, H.; Maenohara, S.; Ohishi, M. Uric Acid Level and New-Onset Atrial Fibrillation in the Japanese General Population—Longitudinal Study. Circ. J. 2018, 83, 156-163. [CrossRef]

68. Llach, A.; E Molina, C.; Prat-Vidal, C.; Fernandes, J.; Casadó, V.; Ciruela, F.; Lluís, C.; Franco, R.; Cinca, J.; Hove-Madsen, L. Abnormal calcium handling in atrial fibrillation is linked to up-regulation of adenosine A2A receptors. Eur. Heart J. 2010, 32, 721-729. [CrossRef]

69. Li, N.; Hansen, B.J.; Fedorov, V.V. Response by Li et al to Letter Regarding Article, “Adenosine-Induced Atrial Fibrillation: Localized Reentrant Drivers in Lateral Right Atria Due to Heterogeneous Expression of Adenosine A1 Receptors and GIRK4 Subunits in the Human Heart". Circulation 2016, 134, e648-e649. [CrossRef]

70. Saadjian, A.Y.; Lévy, S.; Franceschi, F.; Zouher, I.; Paganelli, F.; Guieu, R.P. Role of Endogenous Adenosine as a Modulator of Syncope Induced During Tilt Testing. Circulation 2002, 106, 569-574. [CrossRef]

71. Deharo, J.-C.; Mechulan, A.; Giorgi, R.; Franceschi, F.; Prevot, S.; Peyrouse, E.; Condo, J.; By, Y.; Ruf, J.; Brignole, M.; et al. Adenosine plasma level and A2A adenosine receptor expression: Correlation with laboratory tests in patients with neurally mediated syncope. Heart 2012, 98, 855-859. [CrossRef] [PubMed] 
72. Saadjian, A.Y.; Gerolami, V.; Giorgi, R.; Mercier, L.; Berge-Lefranc, J.-L.; Paganelli, F.; Ibrahim, Z.; By, Y.; Guéant, J.L.; Lévy, S.; et al. Head-up tilt induced syncope and adenosine A2A receptor gene polymorphism. Eur. Heart J. 2009, 30, 1510-1515. [CrossRef] [PubMed]

73. Guieu, R.; Deharo, J.-C.; Ruf, J.; Mottola, G.; Kipson, N.; Bruzzese, L.; Gérolami, V.; Franceschi, F.; Ungar, A.; Tomaino, M.; et al. Adenosine and Clinical Forms of Neurally-Mediated Syncope. J. Am. Coll. Cardiol. 2015, 66, 204-205. [CrossRef] [PubMed]

74. Brignole, M.; Guieu, R.; Tomaino, M.; Iori, M.; Ungar, A.; Bertolone, C.; Unterhuber, M.; Bottoni, N.; Tesi, F.; Deharo, J.C. Mechanism of syncope without prodromes with normal heart and normal electrocardiogram. Heart Rhythm. 2017, 14, 234-239. [CrossRef]

75. Brignole, M.; Solari, D.; Iori, M.; Bottoni, N.; Guieu, R.; Deharo, J.C.; Information, P.E.K.F.C. Efficacy of theophylline in patients affected by low adenosine syncope. Heart Rhythm. 2016, 13, 1151-1154. [CrossRef]

76. Joulia, F.; Coulange, M.; Desplantes, A.; Barberon, B.; Kipson, N.; Gérolami, V.; Jammes, Y.; Kerbaul, F.; Nee, L.; Fromonot, J.; et al. Purinergic profile of fainting divers is different from patients with vasovagal syncope. Int. J. Cardiol. 2014, 174, 741-743. [CrossRef]

77. Hira, H.S.; Samal, P.; Kaur, A.; Kapoor, S. Plasma level of hypoxanthine/xanthine as markers of oxidative stress with different stages of obstructive sleep apnea syndrome. Ann. Saudi Med. 2014, 34, 308-313. [CrossRef]

78. Saito, H.; Nishimura, M.; Shibuya, E.; Makita, H.; Tsujino, I.; Miyamoto, K.; Kawakami, Y. Tissue hypoxia in sleep apnea syndrome assessed by uric acid and adenosine. Chest 2002, 122, 1686-1694. [CrossRef]

79. Hira, H.S.; Shukla, A.; Kaur, A.; Kapoor, S. Serum uric acid and lactate levels among patients with obstructive sleep apnea syndrome: Which is a better marker of hypoxemia? Ann. Saudi Med. 2012, 32, 37-42. [CrossRef]

80. Song, A.; Zhang, Y.; Han, L.; Yegutkin, G.; Liu, H.; Sun, K.; D’Alessandro, A.; Li, J.; Karmouty-Quintana, H.; Iriyama, T.; et al. Erythrocytes retain hypoxic adenosine response for faster acclimatization upon re-ascent. Nat. Commun. 2017, 8, 14108. [CrossRef]

81. Tang, L.; Parker, M.; Fei, Q.; Loutzenhiser, R. Afferent arteriolar adenosine A2a receptors are coupled to KATP in in vitro perfused hydronephrotic rat kidney. Am. J. Physiol. Content 1999, 277, F926-F933. [CrossRef] [PubMed]

82. Kost, C.K.; Herzer, W.A.; Rominski, B.R.; Mi, Z.; Jackson, E.K. Diuretic response to adenosine A(1) receptor blockade in normotensive and spontaneously hypertensive rats: Role of pertussis toxin-sensitive G-proteins. J. Pharmacol. Exp. Ther. 2000, 292, 752-760. [PubMed]

83. Galie, N.; Humbert, M.; Vachiery, J.L.; Gibbs, S.; Lang, I.; Torbicki, A.; Simonneau, G.; Peacock, A.; Vonk Noordegraaf, A.; Beghetti, M.; et al. 2015 ESC/ERS guidelines for the diagnosis and treatment of pulmonary hypertension. Rev. Esp. Cardiol. (Engl. Ed.) 2016, 69, 177. [PubMed]

84. Modesti, P.A.; Vanni, S.; Morabito, M.; Modesti, A.; Marchetta, M.; Gamberi, T.; Sofi, F.; Savia, G.; Mancia, G.; Gensini, G.F.; et al. Role of Endothelin-1 in Exposure to High Altitude. Circulation 2006, 114, 1410-1416. [CrossRef]

85. Man, F.H.-D.; Tu, L.; Handoko, L.; Rain, S.; Ruiter, G.; François, C.; Schalij, I.; Dorfmüller, P.; Simonneau, G.; Fadel, E.; et al. Dysregulated renin-angiotensin-aldosterone system contributes to pulmonary arterial hypertension. Am. J. Respir. Crit. Care Med. 2012, 186, 780-789. [CrossRef]

86. Xu, M.; Gong, Y.; Su, M.; Dai, Z.; Dai, S.; Bao, S.; Li, N.; Zheng, R.; He, J.; Chen, J.; et al. Absence of the adenosine A2A receptor confers pulmonary arterial hypertension and increased pulmonary vascular remodeling in mice. J. Vasc. Res. 2010, 48, 171-183. [CrossRef]

87. Ponikowski, P.; Voors, A.A.; Anker, S.D.; Bueno, H.; Cleland, J.G.F.; Coats, A.J.S.; Falk, V.; González-Juanatey, J.R.; Harjola, V.P.; Jankowska, E.A.; et al. 2016 ESC guidelines for the diagnosis and treatment of acute and chronic heart failure. Rev. Esp. Cardiol. (Engl. Ed.) 2016, 69, 1167.

88. Morgan, J.M.; McCormack, D.G.; Griffiths, M.J.; Morgan, C.J.; Barnes, P.J.; Evans, T.W. Adenosine as a vasodilator in primary pulmonary hypertension. Circulation 1991, 84, 1145-1149. [CrossRef]

89. Rankin, A.C.; Brooks, R.; Ruskin, J.N.; McGovern, B.A. Adenosine and the treatment of supraventricular tachycardia. Am. J. Med. 1992, 92, 655-664. [CrossRef]

90. Coli, S.; Mantovani, F.; Ferro, J.; Gonzi, G.; Zardini, M.; Ardissino, D. Adenosine-induced severe bronchospasm in a patient without pulmonary disease. Am. J. Emerg. Med. 2012, 30, 2082.e3-2082.e5. [CrossRef]

91. Crea, F.; El-Tamimi, H.; Vejar, M.; Kaski, J.C.; Davies, G.; Maseri, A. Adenosine-induced chest pain in patients with silent and painful myocardial ischaemia: Another clue to the importance of generalized defective perception of painful stimuli as a cause of silent ischaemia. Eur. Heart J. 1988, 9, 34-39. [CrossRef] [PubMed] 
92. Brodsky, M.A.; Hwang, C.; Hunter, D.; Chen, P.-S.; Smith, D.; Ariani, M.; Johnston, W.D.; Allen, B.J.; Chun, J.G.; Gold, C.R. Life-threatening alterations in heart rate after the use of adenosine in atrial flutter. Am. Heart J. 1995, 130, 564-571. [CrossRef]

93. Webster, D.P.; Daar, A.A. Prolonged bradyasystole and seizures following intravenous adenosine for supraventricular tachycardia. Am. J. Emerg. Med. 1993, 11, 192-194. [CrossRef]

94. Christopher, M.; Key, C.B.; E Persse, D. Refractory asystole and death following the prehospital administration of adenosine. Prehospital. Emerg. Care 2000, 4, 196-198. [CrossRef]

95. Dunn, J.S.; Brost, B. Fetal bradycardia after IV adenosine for maternal PSVT. Am. J. Emerg. Med. 2000, 18, 234-235. [CrossRef]

96. Tan, H.L.; Spekhorst, H.H.; Peters, R.J.; Wilde, A.A. Adenosine induced ventricular arrhythmias in the emergency room. Pacing Clin. Electrophysiol. 2001, 24, 450-455. [CrossRef]

97. Mallet, M. Proarrhythmic effects of adenosine: A review of the literature. Emerg. Med. J. 2004, 21, 408-410. [CrossRef]

98. Harrington, M.G.R.; Froelich, C.E.G.; Harrington, G.R.; Froelich, E.G. Adenosine-induced Torsades de Pointes. Chest 1993, 103, 1299-1301. [CrossRef]

99. Viskin, S.; Rosso, R.; Rogowski, O.; Belhassen, B.; Levitas, A.; Wagshal, A.; Katz, A.; Fourey, D.; Zeltser, D.; Oliva, A.; et al. Provocation of sudden heart rate oscillation with adenosine exposes abnormal QT responses in patients with long QT syndrome: A bedside test for diagnosing long QT syndrome. Eur. Heart J. 2005, 27, 469-475. [CrossRef]

100. Wesley, R.C.; Turnquest, P. Torsades de pointe after intravenous adenosine in the presence of prolonged QT syndrome. Am. Heart J. 1992, 123, 794-796. [CrossRef]

101. Celiker, A.; Tokel, K.; Cil, E.; Özkutlu, S.; Özme, Ç. Adenosine Induced Torsades de Pointes in a Child with Congenital Long QT Syndrome. Pacing Clin. Electrophysiol. 1994, 17, 1814-1817. [CrossRef] [PubMed]

102. Teodorovich, N.; Margolin, E.; Kogan, Y.; Paz, O.; Swissa, M. Torsades de pointes after adenosine administration. J. Electrocardiol. 2016, 49, 171-173. [CrossRef] [PubMed]

103. Brignole, M.; Deharo, J.-C.; Guieu, R. Syncope and Idiopathic (Paroxysmal) AV Block. Cardiol. Clin. 2015, 33, 441-447. [CrossRef] [PubMed]

104. Day, S.C.; Cook, E.; Funkenstein, H.; Goldman, L. Evaluation and outcome of emergency room patients with transient loss of consciousness. Am. J. Med. 1982, 73, 15-23. [CrossRef]

105. Silverstein, M.D.; Singer, D.E.; Mulley, A.G.; Thibault, G.E.; Barnett, G.O. Patients with syncope admitted to medical intensive care units. JAMA 1982, 248, 1185-1189. [CrossRef]

106. Del Rosso, A.; Bartoletti, A.; Brignole, M. The clinical utility and diagnostic value of the head-up tilt testing (HUT) protocol. J. Cardiovasc. Electrophysiol. 2004, 15, 615-616.

107. Brignole, M.; Gaggioli, G.; Menozzi, C.; Gianfranchi, L.; Bartoletti, A.; Bottoni, N.; Lolli, G.; Oddone, D.; Del Rosso, A.; Pellinghelli, G. Adenosine-induced atrioventricular block in patients with unexplained syncope: The diagnostic value of ATP testing. Circulation 1997, 96, 3921-3927. [CrossRef]

108. Fromonot, J.; Chaumet, G.; Gavarry, O.; Rostain, J.-C.; Lucciano, M.; Joulia, F.; Brignole, M.; Deharo, J.-C.; Guieu, R.; Boussuges, A. Hyperoxia Improves Hemodynamic Status During Head-up Tilt Testing in Healthy Volunteers. Medicine 2016, 95, e2876. [CrossRef]

109. Pinto-Duarte, A.; Coelho, J.E.; Cunha, R.A.; Ribeiro, J.; Sebastião, A.M. Adenosine A2A receptors control the extracellular levels of adenosine through modulation of nucleoside transporters activity in the rat hippocampus. J. Neurochem. 2005, 93, 595-604. [CrossRef]

110. Deharo, J.-C.; Brignole, M.; Guieu, R. Adenosine hypersensitivity and atrioventricular block. Herzschrittmachertherapie und Elektrophysiologie 2018, 29, 166-170. [CrossRef]

111. Cohen, F.R.; Lazareno, S.; Birdsall, N.J. The affinity of adenosine for the high- and low-affinity states of the human adenosine A1 receptor. Eur. J. Pharmacol. 1996, 309, 111-114. [CrossRef]

112. Brignole, M.; Iori, M.; Solari, D.; Bottoni, N.; Rivasi, G.; Ungar, A.; Deharo, J.C.; Guieu, R. Efficacy of theophylline in patients with syncope without prodromes with normal heart and normal ECG. Int. J. Cardiol. 2019, 289, 70-73. [CrossRef] [PubMed]

113. Joulia, F.; Coulange, M.; Lemaitre, F.; Costalat, G.; Franceschi, F.; Gariboldi, V.; Nee, L.; Fromonot, J.; Bruzzese, L.; Gravier, G.; et al. Plasma adenosine release is associated with bradycardia and transient loss of consciousness during experimental breath-hold diving. Int. J. Cardiol. 2013, 168, 138-141. [CrossRef] [PubMed] 
114. Sacramento, J.F.; Melo, B.; Conde, S.V. Adenosine Mediates Hypercapnic Response in the Rat Carotid Body via A2A and A2B Receptors. Results Probl. Cell Differ. 2018, 107, 89-93. [CrossRef]

115. American Sleep Apnea Assocication. Available online: https://www.sleepapnea.org/learn/sleep-apneainformation-clinicians/ (accessed on 5 April 2020).

116. Harding, S.M. Complications and consequences of obstructive sleep apnea. Curr. Opin. Pulm. Med. 2000, 6, 485-489. [CrossRef] [PubMed]

117. Morote-Garcia, J.C.; Rosenberger, P.; Kuhlicke, J.; Eltzschig, H.K. HIF-1-dependent repression of adenosine kinase attenuates hypoxia-induced vascular leak. Blood 2008, 111, 5571-5580. [CrossRef]

118. Jensen, M.L.F.; Vestergaard, M.B.; Tønnesen, P.; Larsson, H.B.W.; Jennum, P. Cerebral blood flow, oxygen metabolism, and lactate during hypoxia in patients with obstructive sleep apnea. Sleep 2018, 41. [CrossRef]

119. Bjorness, T.E.; Greene, R.W. Adenosine and Sleep. Curr. Neuropharmacol. 2009, 7, 238-245. [CrossRef]

120. Carley, D.W.; Radulovacki, M. Role of Peripheral Adenosine A1 Receptors in the Regulation of Sleep Apneas in Rats. Exp. Neurol. 1999, 159, 545-550. [CrossRef]

121. Görlach, A. Control of adenosine transport by hypoxia. Circ. Res. 2005, 97, 1-3. [CrossRef]

122. Coney, A.; Marshall, J.M. Role of adenosine and its receptors in the vasodilatation induced in the cerebral cortex of the rat by systemic hypoxia. J. Physiol. 1998, 509, 507-518. [CrossRef] [PubMed]

123. Feoktistov, I.; Ryzhov, S.; Zhong, H.; Goldstein, A.E.; Matafonov, A.; Zeng, D.; Biaggioni, I. Hypoxia Modulates Adenosine Receptors in Human Endothelial and Smooth Muscle Cells Toward an A2B Angiogenic Phenotype. Hypertension 2004, 44, 649-654. [CrossRef] [PubMed]

124. Bruzzese, L.; Fromonot, J.; By, Y.; Durand-Gorde, J.M.; Condo, J.; Kipson, N.; Guieu, R.; Fenouillet, E.; Ruf, J. NF-kappaB enhances hypoxia-driven T-cell immunosuppression via upregulation of adenosine $\mathrm{A}(2 \mathrm{~A})$ receptors. Cell Signal. 2014, 26, 1060-1067. [CrossRef] [PubMed]

125. Eltzschig, H.K.; Abdulla, P.; Hoffman, E.; Hamilton, K.E.; Daniels, D.; Schönfeld, C.; Löffler, M.; Reyes, G.; Duszenko, M.; Karhausen, J.; et al. HIF-1-dependent repression of equilibrative nucleoside transporter (ENT) in hypoxia. J. Exp. Med. 2005, 202, 1493-1505. [CrossRef]

126. Liu, H.; Zhang, Y.; Wu, H.; D’Alessandro, A.; Yegutkin, G.; Song, A.; Sun, K.; Li, J.; Cheng, N.-Y.; Huang, A.; et al. Beneficial Role of Erythrocyte Adenosine A2B Receptor-Mediated AMP-Activated Protein Kinase Activation in High-Altitude Hypoxia. Circulatyion 2016, 134, 405-421. [CrossRef]

127. Sun, K.; Liu, H.; Song, A.; Manalo, J.M.; D'Alessandro, A.; Hansen, K.C.; Kellems, R.E.; Eltzschig, H.K.; Blackburn, M.R.; Roach, R.; et al. Erythrocyte purinergic signaling components underlie hypoxia adaptation. J. Appl. Physiol. 2017, 123, 951-956. [CrossRef]

128. Paterson, G.G.; Young, J.M.; Willson, J.A.; Graham, C.J.; Dru, R.C.; Lee, E.W.; Torpey, G.S.; Walmsley, S.R.; Chan, M.V.; Warner, T.D.; et al. Hypoxia Modulates Platelet Purinergic Signalling Pathways. Thromb. Haemost. 2019, 120, 253-261. [CrossRef]

129. Laxson, D.D.; Homans, D.C.; Bache, R.J. Inhibition of adenosine-mediated coronary vasodilation exacerbates myocardial ischemia during exercise. Am. J. Physiol. Circ. Physiol. 1993, 265, H1471-H1477. [CrossRef]

130. Duncker, D.J.; Stubenitsky, R.; Verdouw, P.D. Role of adenosine in the regulation of coronary blood flow in swine at rest and during treadmill exercise. Am. J. Physiol. Content 1998, 275, H1663-H1672. [CrossRef]

131. Bardenheuer, H.; Schrader, J. Supply-to-demand ratio for oxygen determines formation of adenosine by the heart. Am. J. Physiol. Circ. Physiol. 1986, 250, H173-H180. [CrossRef]

132. Martin, B.J.; McClanahan, T.B.; Van Wylen, D.G.; Gallagher, K.P. Effects of ischemia, preconditioning, and adenosine deaminase inhibition on interstitial adenosine levels and infarct size. Basic Res. Cardiol 1997, 92, 240-251. [CrossRef] [PubMed]

133. Harrison, G.; Willis, R.J.; Headrick, J.P. Extracellular adenosine levels and cellular energy metabolism in ischemically preconditioned rat heart. Cardiovasc. Res. 1998, 40, 74-87. [CrossRef]

134. Toombs, C.F.; McGee, S.; Johnston, W.E.; Vinten-Johansen, J. Myocardial protective effects of adenosine. Infarct size reduction with pretreatment and continued receptor stimulation during ischemia. Circulation 1992, 86, 986-994. [CrossRef]

135. Cohen, M.V.; Downey, J.M. Adenosine: Trigger and mediator of cardioprotection. Basic Res. Cardiol. 2007, 103, 203-215. [CrossRef]

136. Headrick, J.P.; Lasley, R.D. Adenosine Receptors and Reperfusion Injury of the Heart. Handb. Exp. Pharmacol. 2009, 193, 189-214. [CrossRef] 
137. Reichelt, M.; Shanu, A.; Willems, L.; Witting, P.K.; Ellis, N.A.; Blackburn, M.; Headrick, J.P. Endogenous Adenosine Selectively Modulates Oxidant Stress via the A1 Receptor in Ischemic Hearts. Antioxid. Redox Signal. 2009, 11, 2641-2650. [CrossRef]

138. Rothermel, B.A.; Hill, J. Adenosine A3 receptor and cardioprotection: Enticing, enigmatic, elusive. Circulation 2008, 118, 1691-1693. [CrossRef]

139. Mubagwa, K.; Flameng, W. Adenosine, adenosine receptors and myocardial protection: An updated overview. Cardiovasc. Res. 2001, 52, 25-39. [CrossRef]

140. Paganelli, F.; Saadjian, A.; Sampol, J.J.; Maixent, J.; Levy, S.; Guieu, R. Effects of percutaneous transluminal coronary angioplasty on coronary adenosineconcentrations in humans. Eur. J. Clin. Investig. 2000, 30, 105-110. [CrossRef]

141. Tommasi, S.; Carluccio, E.; Bentivoglio, M.; Corea, L.; Picano, E. Low-dose dipyridamole infusion acutely increases exercise capacity in angina pectoris: A double-blind, placebo controlled crossover stress echocardiographic study. J. Am. Coll. Cardiol. 2000, 35, 83-88. [CrossRef]

142. Heidland, U.E.; Heintzen, M.P.; Michel, C.J.; Strauer, B.E. Intracoronary administration of dipyridamole prior to percutaneous transluminal coronary angioplasty provides a protective effect exceeding that of ischemic preconditioning. Coron. Artery Dis. 2000, 11, 607-613. [CrossRef] [PubMed]

143. Bulluck, H.; Sirker, A.; Loke, Y.K.; Garcia-Dorado, D.; Hausenloy, D.J. Clinical benefit of adenosine as an adjunct to reperfusion in ST-elevation myocardial infarction patients: An updated meta-analysis of randomized controlled trials. Int. J. Cardiol. 2015, 202, 228-237. [CrossRef] [PubMed]

144. Skyschally, A.; Caster, P.; Iliodromitis, E.K.; Schulz, R.; Kremastinos, D.T.; Heusch, G. Ischemic postconditioning: Experimental models and protocol algorithms. Basic Res. Cardiol. 2009, 104, 469-483. [CrossRef] [PubMed]

145. Johnston-Cox, H.A.; Koupenova, M.; Ravid, K. A2 adenosine receptors and vascular pathologies. Arter. Thromb. Vasc. Boil. 2012, 32, 870-878. [CrossRef]

146. Feoktistov, I.; Biaggioni, I.; Cronstein, B.N. Adenosine receptors in wound healing, fibrosis and angiogenesis. Handb. Exp. Pharmacol. 2009, 193, 383-397. [CrossRef]

147. Montesinos, M.C.; Gadangi, P.; Longaker, M.; Sung, J.; Levine, J.; Nilsen, D.; Reibman, J.; Li, M.; Jiang, C.K.; Hirschhorn, R.; et al. Wound healing is accelerated by agonists of adenosine A2 (G alpha s-linked) receptors. J. Exp. Med. 1997, 186, 1615-1620. [CrossRef]

148. Dubey, R.K.; Baruscotti, I.; Stiller, R.; Fingerle, J.; Gillespie, D.G.; Mi, Z.; Leeners, B.; Imthurn, B.; Rosselli, M.; Jackson, E.K. Adenosine, Via A2B Receptors, Inhibits Human (P-SMC) Progenitor Smooth Muscle Cell Growth. Hypertension 2019, 75, 109-118. [CrossRef]

149. Yang, D.; Koupenova, M.; McCrann, N.J.; Kopeikina, K.J.; Kagan, H.M.; Schreiber, B.; Ravid, K. The A2b adenosine receptor protects against vascular injury. Proc. Natl. Acad. Sci. USA 2008, 105, 792-796. [CrossRef]

150. Fromonot, J.; Dignat-Georges, F.; Rossi, P.; Mottola, G.; Kipson, N.; Ruf, J.; Bonello, L.; Guieu, R.; Paganelli, F. Ticagrelor Improves Peripheral Arterial Function in Acute Coronary Syndrome Patients. J. Am. Coll. Cardiol. 2016, 67, 1967-1968. [CrossRef]

151. Chen, J.-F.; Eltzschig, H.K.; Fredholm, B.B. Adenosine receptors as drug targets-what are the challenges? Nat. Rev. Drug Discov. 2013, 12, 265-286. [CrossRef]

152. Effendi, W.; Nagano, T.; Kobayashi, K.; Nishimura, Y. Focusing on Adenosine Receptors as a Potential Targeted Therapy in Human Diseases. Cells 2020, 9, 785. [CrossRef] [PubMed]

153. Kitakaze, M.; Hori, M.; Kamada, T. Role of adenosine and its interaction with adrenoceptor activity in ischaemic and reperfusion injury of the myocardium. Cardiovasc. Res. 1993, 27, 18-27. [CrossRef] [PubMed]

154. Kocić, I.; Korolkiewicz, K. Negative inotropic action of alpha-1a adrenoceptor blocking agents: Role of adenosine and ATP-sensitive K+ channels. Gen. Pharmacol. Vasc. Syst. 1998, 30, 351-356. [CrossRef]

155. Jackson, E.K.; Gillespie, D.G.; Mi, Z.; Cheng, N. Adenosine Receptors Influence Hypertension in Dahl Salt-Sensitive Rats. Hypertension 2018, 72, 511-521. [CrossRef] [PubMed]

156. Li, L.; Lai, E.Y.; Huang, Y.; Eisner, C.; Mizel, D.; Wilcox, C.S.; Schnermann, J. Renal afferent arteriolar and tubuloglomerular feedback reactivity in mice with conditional deletions of adenosine 1 receptors. Am. J. Physiol. Physiol. 2012, 303, F1166-F1175. [CrossRef] [PubMed] 
157. Lai, E.Y.; Martinka, P.; Fähling, M.; Mrowka, R.; Steege, A.; Gericke, A.; Sendeski, M.; Persson, P.; Persson, A.E.G.; Patzak, A. Adenosine Restores Angiotensin II-Induced Contractions by Receptor-Independent Enhancement of Calcium Sensitivity in Renal Arterioles. Circ. Res. 2006, 99, 1117-1124. [CrossRef]

158. Lai, E.; Patzak, A.; Steege, A.; Mrowka, R.; Brown, R.; Spielmann, N.; Persson, P.; Fredholm, B.; Persson, A. Contribution of adenosine receptors in the control of arteriolar tone and adenosine-angiotensin II interaction. Kidney Int. 2006, 70, 690-698. [CrossRef]

159. Kuan, C.-J.; Herzer, W.A.; Jackson, E.K. Cardiovascular and Renal Effects of Blocking A1 Adenosine Receptors. J. Cardiovasc. Pharmacol. 1993, 21, 822-828. [CrossRef]

160. Wang, Y.; Yang, J.N.; Arner, A.; Boels, P.J.M.; Fredholm, B.B. Adenosine A1 receptors and vascular reactivity. Acta Physiol. 2010, 199, 211-220. [CrossRef]

161. Yadav, V.R.; Teng, B.; Mustafa, S.J. Enhanced A(1) adenosine receptor-induced vascular contractions in mesenteric artery and aorta of in L-NAME mouse model of hypertension. Eur. J. Pharmacol. 2019, 842, 111-117. [CrossRef]

162. Maimon, N.; Titus, P.A.; Sarelius, I.H. Pre-exposure to adenosine, acting via A2Areceptors on endothelial cells, alters the protein kinase A dependence of adenosine-induced dilation in skeletal muscle resistance arterioles. J. Physiol. 2014, 592, 2575-2590. [CrossRef] [PubMed]

163. Zou, A.-P.; Wu, F.; Li, P.-L.; Cowley, A.W. Effect of chronic salt loading on adenosine metabolism and receptor expression in renal cortex and medulla in rats. Hypertension 1999, 33, 511-516. [CrossRef] [PubMed]

164. Ansari, H.R.; Nadeem, A.; Talukder, M.A.H.; Sakhalkar, S.; Mustafa, S.J. Evidence for the involvement of nitric oxide in A2B receptor-mediated vasorelaxation of mouse aorta. Am. J. Physiol. Circ. Physiol. 2007, 292, H719-H725. [CrossRef] [PubMed]

165. Teng, B.; Fil, D.; Tilley, S.L.; Ledent, C.; Krahn, T.; Mustafa, S.J. Functional and RNA expression profile of adenosine receptor subtypes in mouse mesenteric arteries. J. Cardiovasc. Pharmacol. 2013, 61, 70-76. [CrossRef] [PubMed]

166. Zou, A.-P.; Nithipatikom, K.; Li, P.-L.; Cowley, A.W. Role of renal medullary adenosine in the control of blood flow and sodium excretion. Am. J. Physiol. Content 1999, 276, R790-R798. [CrossRef] [PubMed]

167. Zhang, W.; Zhang, Y.; Wang, W.; Dai, Y.; Ning, C.; Luo, R.; Sun, K.; Glover, L.; Grenz, A.; Sun, H.; et al. Elevated ecto-5'-nucleotidase-mediated increased renal adenosine signaling via A2B adenosine receptor contributes to chronic hypertension. Circ. Res. 2013, 112, 1466-1478. [CrossRef] [PubMed]

168. Varani, K.; Manfredini, R.; Iannotta, V.; Pancaldi, C.; Cattabriga, E.; Uluoglu, C.; Borea, P.A.; Portaluppi, F. Effects of Doxazosin and Propranolol on A2AAdenosine Receptors in Essential Hypertension. Hypertension 2002, 40, 909-913. [CrossRef]

169. Silhol, F.; Marlinge, M.; Guiol, C.; Chefrour, M.; Mace, P.; Criado, C.; Kipson, N.; Vaisse, B.; Vairo, D.; Sarlon, G.; et al. Characterization of adenosine A2 receptors in peripheral blood mononuclear cells of patients with fibromuscular dysplasia. Hypertens. Res. 2019, 43, 466-469. [CrossRef]

170. Galié, N.; Torbicki, A.; Barst, R.; Dartevelle, P.; Haworth, S.; Higenbottam, T.; Olschewski, H.; Peacock, A.; Pietra, G.; Rubin, L.J.; et al. Guidelines on diagnosis and treatment of pulmonary arterial hypertension. The Task Force on Diagnosis and Treatment of Pulmonary Arterial Hypertension of the European Society of Cardiology. Eur. Heart J. 2004, 25, 2243-2278. [CrossRef]

171. Xu, X.-Q.; Jing, Z.-C. High-altitude pulmonary hypertension. Eur. Respir. Rev. 2009, 18, 13-17. [CrossRef]

172. Humbert, M.; Morrell, N.W.; Archer, S.L.; Stenmark, K.R.; MacLean, M.; Lang, I.M.; Christman, B.W.; Weir, E.; Eickelberg, O.; Voelkel, N.F.; et al. Cellular and molecular pathobiology of pulmonary arterial hypertension. J. Am. Coll. Cardiol. 2004, 43, S13-S24. [CrossRef] [PubMed]

173. Alencar, A.K.N.; Montes, G.C.; Barreiro, E.J.; Sudo, R.T.; Zapata-Sudo, G. Adenosine Receptors as Drug Targets for Treatment of Pulmonary Arterial Hypertension. Front. Pharmacol. 2017, 8, 858. [CrossRef] [PubMed]

174. Saadjian, A.Y.; Paganelli, F.; Gaubert, M.; Levy, S.; Guieu, R.P. Adenosine plasma concentration in pulmonary hypertension. Cardiovasc. Res. 1999, 43, 228-236. [CrossRef]

175. Saadjian, A.Y.; Paganelli, F.; Juin, M.A.; Devaux, C.; Lévy, S.; Guieu, R.P. Plasmabeta-endorphin and adenosine concentration in pulmonary hypertension. Am. J. Cardiol. 2000, 85, 858-863. [CrossRef]

176. Mann, D.L. Innate immunity and the failing heart: The cytokine hypothesis revisited. Circ. Res. 2015, 116, 1254-1268. [CrossRef]

177. Funaya, H.; Kitakaze, M.; Node, K.; Minamino, T.; Komamura, K.; Hori, M. Plasma Adenosine Levels Increase in Patients With Chronic Heart Failure. Circulation 1997, 95, 1363-1365. [CrossRef] 
178. Franceschi, F.; Deharo, J.-C.; Giorgi, R.; By, Y.; Monserrat, C.; Condo, J.; Ibrahim, Z.; Saadjian, A.; Guieu, R. Peripheral plasma adenosine release in patients with chronic heart failure. Heart 2008, 95, 651-655. [CrossRef]

179. Gaubert, M.; Marlinge, M.; Kerbaul, F.; Resseguier, N.; Laine, M.; Cautella, J.; Cordier, C.; Colomb, B.; Kipson, N.; Thuny, F.; et al. Adenosine Plasma Level and A2A Receptor Expression in Patients with Cardiogenic Shock. Crit. Care Med. 2018, 46, e874-e880. [CrossRef]

180. Asakura, M.; Asanuma, H.; Kim, J.; Liao, Y.; Nakamaru, K.; Fujita, M.; Komamura, K.; Isomura, T.; Furukawa, H.; Tomoike, H.; et al. Impact of Adenosine Receptor Signaling and Metabolism on Pathophysiology in Patients with Chronic Heart Failure. Hypertens. Res. 2007, 30, 781-787. [CrossRef]

181. Matherne, G.P.; Linden, J.; Byford, A.M.; Gauthier, N.S.; Headrick, J.P. Transgenic A1 adenosine receptor overexpression increases myocardial resistance to ischemia. Proc. Natl. Acad. Sci. USA 1997, 94, 6541-6546. [CrossRef]

182. Zucchi, R.; Cerniway, R.J.; Ronca-Testoni, S.; Morrison, R.R.; Ronca, G.; Matherne, G.P. Effect of cardiac A(1) adenosine receptor overexpression on sarcoplasmic reticulum function. Cardiovasc. Res. 2002, 53, 326-333. [CrossRef]

183. Varani, K.; Laghi-Pasini, F.; Camurri, A.; Capecchi, P.L.; Maccherini, M.; Diciolla, F.; Ceccatelli, L.; Lazzerini, P.E.; Ulouglu, C.; Cattabeni, F.; et al. Changes of peripheral A 2A adenosine receptors in chronic heart failure and cardiac transplantation. FASEB J. 2002, 17, 280-282. [CrossRef]

184. Gullestad, L.; Ueland, T.; Vinge, L.E.; Finsen, A.; Yndestad, A.; Aukrust, P. Inflammatory Cytokines in Heart Failure: Mediators and Markers. Cardiology 2012, 122, 23-35. [CrossRef]

185. Zhai, Y.-J.; Liu, P.; He, H.-R.; Zheng, X.-W.; Wang, Y.; Yang, Q.-T.; Lu, T.; Lyu, J. The Association of ADORA2A and ADORA2B Polymorphisms with the Risk and Severity of Chronic Heart Failure: A Case-Control Study of a Northern Chinese Population. Int. J. Mol. Sci. 2015, 16, 2732-2746. [CrossRef]

186. Zhang, H.; Zhong, H.; Everett, T.H.; Wilson, E.; Chang, R.; Zeng, D.; Belardinelli, L.; Olgin, J.E. Blockade of $\mathrm{A} 2 \mathrm{~B}$ adenosine receptor reduces left ventricular dysfunction and ventricular arrhythmias 1 week after myocardial infarction in the rat model. Heart Rhythm. 2014, 11, 101-109. [CrossRef]

187. Lu, Z.; Fassett, J.; Xu, X.; Hu, X.; Zhu, G.; French, J.; Zhang, P.; Schnermann, J.; Bache, R.J.; Chen, Y. Adenosine A3 receptor deficiency exerts unanticipated protective effects on the pressure-overloaded left ventricle. Circulation 2008, 118, 1713-1721. [CrossRef] 